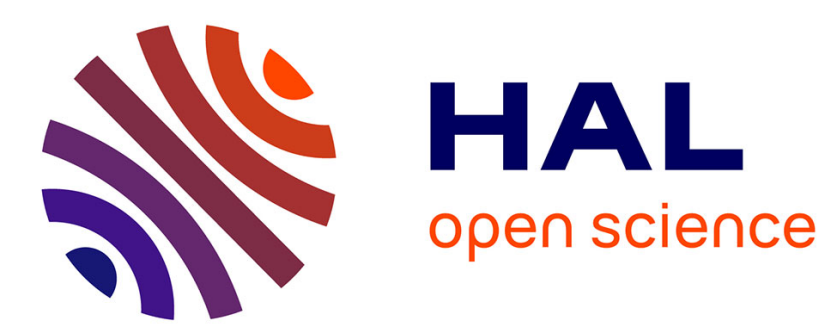

\title{
Bioactivity of compounds secreted by symbiont bacteria of Nudibranchs from Indonesia
}

Rhesi Kristiana, Gilles Bedoux, Gerard Pals, Wayan Mudianta, Laure Taupin, Christel Marty, Meezan Ardhanu Asagabaldan, Diah Ayuningrum, Agus

Trianto, Nathalie Bourgougnon, et al.

\section{To cite this version:}

Rhesi Kristiana, Gilles Bedoux, Gerard Pals, Wayan Mudianta, Laure Taupin, et al.. Bioactivity of compounds secreted by symbiont bacteria of Nudibranchs from Indonesia. PeerJ Preprints, 2019, 10.7287/peerj.preprints.27745v1 . hal-02385065

\section{HAL Id: hal-02385065 https://hal.science/hal-02385065}

Submitted on 28 Nov 2019

HAL is a multi-disciplinary open access archive for the deposit and dissemination of scientific research documents, whether they are published or not. The documents may come from teaching and research institutions in France or abroad, or from public or private research centers.
L'archive ouverte pluridisciplinaire HAL, est destinée au dépôt et à la diffusion de documents scientifiques de niveau recherche, publiés ou non, émanant des établissements d'enseignement et de recherche français ou étrangers, des laboratoires publics ou privés. 


\section{Bioactivity of compounds secreted by symbiont bacteria of Nudibranchs from Indonesia}

Rhesi Kristiana ${ }^{\text {Corresp., } 1}{ }^{\text {, Gilles Bedoux }}{ }^{2}$, Gerard Pals ${ }^{3}$, I Wayan Mudianta ${ }^{4}$, Laure Taupin ${ }^{2}$, Christel Marty ${ }^{2}$, Meezan Ardhanu Asagabaldan ${ }^{1}$, Diah Ayuningrum ${ }^{1}$, Agus Trianto ${ }^{5}$, Nathalie Bourgougnon ${ }^{2}$, Ocky Karna Radjasa ${ }^{5}$, Agus Sabdono ${ }^{5}$

${ }^{1}$ Department of Coastal Resource Management, Universities Diponegoro, Semarang, Central Java, Indonesia

2 Laboratory of Marine Biotechnology and Chemistry, Université de Bretagne Sud, Vannes, Bretagne, France

3 Center for Connective Tissue research, vU University medical center, Amsterdam, Netherlands

4 Chemical Analysis Study Program, Universitas Pendidikan Ganesha, Singaraja, Bali, Indonesia

5 Department of Marine Sciences, Faculty of Fisheries and Marine Sciences, Universities Diponegoro, Semarang, Central Java, Indonesia

Corresponding Author: Rhesi Kristiana

Email address: rhesiundip@student.undip.ac.id

The aim of this work was to isolate bacterial symbionts from nudibranchs and subsequently to determine anti-Methicillin resistant Staphylococcus aureus (MRSA), cytotoxicity and anti-HSV-1 activities of bio-compounds. Fifteen species of nudibranchs were collected from Karimunjawa and five species from Bali, respectively. A total of 245 bacteria isolates were obtained. The anti-MRSA activity screening activity indicated 2 isolates of active bacteria. Ethyl acetate extracts from supernatants, indicating secreted compounds, showed an inhibition zone against MRSA at concentrations of $500-1000 \mu \mathrm{g} / \mathrm{ml}$. DNA sequence analysis showed that the strainKJB-07 from Phyllidia coelestis was closely related to Pseudoalteromonas rubra, the strain NP31-01 from Phyllidia varicosa was closely related to Virgibacillus salarius. The extract of $P$. rubra was cytotoxic to Vero cells at a concentration of $75 \mu \mathrm{g} / \mathrm{ml}$. The extract of $V$. salarius presented no cytotoxicity at concentrations of $5-1000 \mu \mathrm{g} / \mathrm{ml}$. No anti-HSV-1 was observed. This is the first reported study describing research on anti-MRSA, cytotoxicity and anti-HSV-1 activity of bacterial symbionts from the viscera of nudibranch. Compounds produced and secreted byPseudoalteromonas rubra and Virgibacillus salarius, symbionts of Nudibranch, had potential anti-MRSA activity. Extracts from $P$. rubra showed cytotoxic effects on Vero cells, whereas extracts from $V$. salarius did not show cytotoxic effects. Three compounds were identified by LC/MS after purification from culture supernatant. 
1 Title: Bioactivity of compounds secreted by symbiont bacteria of Nudibranch from Indonesia 2

3 Authors: Rhesi Kristiana ${ }^{1 *}$, Gilles Bedoux ${ }^{2}$, Gerard Pals ${ }^{3}$, I Wayan Mudianta ${ }^{4}$, Laure Taupin²,

4 Christel Marty ${ }^{2}$, Meezan Ardhanu Asagabaldan ${ }^{1}$, Diah Ayuningrum ${ }^{1}$, Agus Trianto ${ }^{5}$, Nathalie

5 Bourgougnon ${ }^{2}$, Ocky Karna Radjasa ${ }^{5}$, Agus Sabdono ${ }^{5}$

6

\section{Affiliations:}

8 Coastal Resources Management, Faculty of Fisheries and Marine Sciences, Diponegoro

9 University, 50275 Tembalang, Semarang, Indonesia

${ }^{2}$ Laboratory of Marine Biotechnology and Chemistry, EA3884, UBS, IUEM, F-5600 Vannes,

France

$12{ }^{3}$ Center for Connective Tissue research, VU University medical center, De Boelelaan 1117,

13 1081HV, Amsterdam, The Netherlands.

$14{ }^{4}$ Chemical Analysis Study Program, Universitas Pendidikan Ganesha, 81116 Singaraja, Bali,

15 Indonesia

$16{ }^{5}$ Department of Marine Sciences, Faculty of Fisheries and Marine Sciences, Diponegoro

17 University, 50275 Tembalang, Semarang, Indonesia

18 *Correspondence:

19 (Tel) : +62 81228676481

20 (E-mail) : rhesikristiana@gmail.com 


\section{Abstract}

23

24 The aim of this work was to isolate bacterial symbionts from nudibranchs and subsequently to determine anti-

25 Methicillin resistant Staphylococcus aureus (MRSA), cytotoxicity and anti-HSV-1 activities of bio compounds.

26 Fifteen species of nudibranchs were collected from Karimunjawa and five species from Bali, respectively. A total of

27245 bacteria isolates were obtained. The anti-MRSA activity screening activity indicated 2 isolates of active

28 bacteria. Ethyl acetate extracts from supernatants, indicating secreted compounds, showed an inhibition zone against 29 MRSA at concentrations of 500-1000 $\mu \mathrm{g} / \mathrm{ml}$. DNA sequence analysis showed that the strain KJB-07 from Phyllidia coelestis was closely related to Pseudoalteromonas rubra, the strain NP31-01 from Phyllidia varicosa was closely related to Virgibacillus salarius. The extract of P. rubra was cytotoxic to Vero cells at a concentration of $75 \mu \mathrm{g} / \mathrm{ml}$. rubra and Virgibacillus salarius, symbionts of Nudibranch, had potential anti-MRSA activity. Extracts from $P$.

Three compounds were identified by LC/MS after purification from culture supernatant.

Keywords: Nudibranch; Virgibacillus salarius; Pseudoalteromonas rubra; Anti-MRSA activity;

HSV-1; antibiotic

\section{Introduction} germs, which are bacteria, viruses, fungi and parasites. Bacteria are the first cause of diseases. 
health concern. This bacterium is known as methicillin resistant Staphylococcus aureus, or

MRSA. Approximately one-third of the world population has $S$. aureus bacteria on their bodies at any given time, primarily in the nose and on the skin. The bacteria can be present without causing an active infection. According to Centers for Disease Control and Prevention (CDC) approximately $1 \%$ of people has MRSA. There are two ways in which the infection can be acquired hospital-acquired MRSA (HA-MRSA) or community-associated MRSA (CA-MRSA).

54 The MRSA infections caused higher morbidity and mortality compared to non-resistant strains. (Akhi et al., 2017). The rapid emergence of MRSA infection is becoming crucial, as the effectiveness of treatment of MRSA infection decreases due to the ability of bacteria to respond to antibiotics (Guzmán-Blanco et al., 2009). In 2017, according to the World Health Organization (WHO), the resistance to first line drugs to treat infections caused by $S$. aureus was widespread. People with MRSA are estimated to be $64 \%$ more likely to die than people with a non-resistant form of the infection.

The second case is virus infection. Herpes simplex virus (HSV), a DNA virus, is a common human pathogen with between 60 to $95 \%$ of certain populations infected with Herpes simplex virus type 1 (HSV-1), and between 6 to 50\% infected with Herpes simplex virus type 2 (HSV-2). Primary and recurrent herpes virus infections in human represent major risk factors for acquisition of primary HIV-1 infection (Sassi et al., 2008). Acyclovir is the antiviral treatment of choice, but resistance to acyclovir has been reported due to the UL23 gene mutations

67 (Mitterreiter et al., 2016). There is a need to develop new natural source of agents for the management of HSV infections.

The Indonesian archipelago is a hotspot for biodiversity in the world (Gastropoda et al.,

702018 ) and a very rich marine environment. The studies regarding screening of secondary 
71 metabolites-producing bacterial symbionts are important for understanding their biotechnological

72 potential (Radjasa et al., 2011). A few reports have been documented on the potential of

73 bacterial symbionts from Indonesian marine invertebrates, such as coral (Radjasa, et al., 2007),

74 soft coral (Seyed Vahid Shetab-Boushehri, 2012) and sponge (Radjasa, et al., 2007).

75 Since marine tropical diversity also reflects chemical diversity, the isolation of the under-

76 exploited bacterial symbionts from Indonesian nudibranchs offers a great opportunity for

77 discovering novel bio compounds, based on screening against various disease targets. Natural

78 products from cultured symbionts of marine invertebrates present an opportunity to be developed

79 in ways that circumvent environmental and supply problems of pharmaceutical substances.

80 Nudibranchs, belonging to gastropods, are of great interest for research and development of

81 bioactive natural metabolites. These invertebrates are exposed to predators and to surface

82 colonization by microorganisms. For them, the only hope of surviving and fighting effectively

83 against this is to produce compounds that are toxic for infectious bacteria. These compounds

84 have actually been found in a number of organisms and it has been suggested that they represent

85 secondary metabolites from symbiont bacteria (Radjasa et al., 2011).

86 There is one report of symbiotic bacteria in the vestibular gland, associated with the female

87 reproductive system, and in the egg masses of the nudibranch Dendrodoris nigra (Klussmann-

88 Kolb and Brodie, 1999). In 2012, Rod-shaped gram-negative bacteria were revealed in the

89 epithelial cells of the notum and the mantle edge as well as in the adjoining glycocalix near the

90 outer membrane of the epithelial cells (Zhukova and Eliseikina, 2012) and these bacteria were

91 enclosed in secondary vacuoles in the epithelial cells in D. nigra. Several drugs with interesting

92 pharmaceutical properties are currently in clinical trials (Chand and Karuso, 2017). For example,

93 Serpin serine protease produced by Octopus ocellatus has potential antibacterial activity (Wei et 
94 al., 2015), two gastropods Cerastoderma edule and Ostrea edulis present potential antibacterial

95 and antiviral molecules (Defer et al., 2009), tambjamine D an alkaloid isolated from the Tambja

96 eliora, has been reported to have cytotoxic and genotoxic activity (De Oliveira et al., 2007),

97 furthermore the bioactive alkaloid ergopeptine has been extracted from Pleurobranchus forskalii

98 (Wakimoto et al., 2013). Overall, secondary metabolites have only been investigated from a

99 small proportion (<1\%) of Mollusca species (Benkendorff, 2010).

100

In the present study, we explore the possibility of finding anti-MRSA and antiviral

101 molecules from nudibranch's symbiotic bacteria. Twenty nudibranchs species have been

102 collected in Bali and the national park of Karimunjawa, Jepara, in the Java Sea. Symbiont

103 bacteria collections have been isolated from stomach tissues and research of biological activities

104 was performed on supernatants of lysed bacteria. We investigate the anti-MRSA and antiviral 105 activity that can be derived from symbiont bacteria after culture of the bacteria.

106

107

2. Materials and Methods

108 Sampling. This research used samples that were collected from Lovina, Bali and the National

109 Park of Karimunjawa (5'47'21.6'’S 110030'41.9'’E) (March 2017), Jepara Indonesia by SCUBA

110 diving $15-20 \mathrm{~m}$ in depth, at $18-25{ }^{\circ} \mathrm{C}$. The samples of nudibranchs were put into sterile plastic

111 bags, filled with seawater and stored in a cool box (He et al., 2014)(Sabdono et al., 2015), and

112 immediately brought to the laboratory to be identified, studied and to isolate the bacteria.

113 Symbiont bacteria collection and isolation. The nudibranchs were washed three times, using

114 sterile seawater, to remove the impurities still attached to the nudibranchs body. The contents of

115 the stomach called viscera and the body were separated by using a sterile knife and were put in a

116 conical tube that contained sterile seawater. Bacterial isolation was done using the dilution 
117 method $\left(10^{-1}, 10^{-2}, 10^{-3}, 10^{-4}\right)($ Anand et al., 2006). The bacterial inoculation was performed on

118 the ZoBell 2216E agar media [peptone $15 \mathrm{~g} / \mathrm{L}$ (Oxoid Laboratories); yeast (Himedia

119 Laboratories); agar $15 \mathrm{~g} / \mathrm{L}$ (Oxoid Laboratories)] and was incubated at a temperature of $37{ }^{0} \mathrm{C}$ for

1205 days. Bacterial colonies were grown on a plate, and each colony was separated according to

121 shape, elevation and colour. Isolation and purification processes were done in the Tropical

122 Marine Biotechnology Laboratory at Diponegoro University. The pure colonies were maintained

123 in slant cultures at $-20{ }^{0} \mathrm{C}$.

124 Anti-MRSA screening. The antibacterial test was conducted using the overlay method, 245

125 colony-forming units of symbiont bacteria of nudibranchs were cultured in ZoBell 2216E agar

126 media and incubated at $37^{\circ} \mathrm{C}$ for $24 \mathrm{~h}$ (Radjasa, et al., 2007). The pathogenic bacterium

127 Staphylococcus aureus (Strain MRSA from Kariadi Hospital in Semarang, Indonesia, resistant

128 for oxacillin, gentamicin, benzylpenicillin, ciprofloxacin, levofloxacin, tetracycline) was cultured

129 in Muller-Hinton broth (Difco Laboratories) with a shaker condition of $150 \mathrm{rpm}$ at $37^{0} \mathrm{C}$ for 24

130 h. The antibacterial test was conducted by mixing S. aureus with $0.5 \mathrm{McF}$ arland standard in soft

131 agar media and pouring into the petri dishes containing the marine bacterial colonies. All

132 screening was performed in triplicate experiments. Clear zones were observed following

133 overnight incubation at $37^{\circ} \mathrm{C}$. The clear zone around bacterial colonies, was an indicator that

134 there has been antibacterial activity (Defer et al., 2009). Isolates that pexhibited anti-MRSA

135 activity were chosen for further characterization of bioactive compounds, molecular

136 identification, cytotoxicity and anti-HSV activity.

137 Bioactive compound extraction. Active isolates of bacterial symbionts of nudibranchs against

138 MRSA were cultured in $3 \mathrm{~L}$ of nutrient broth (Oxoid Laboratories) with seawater-based medium

139 for 6 days (Singh et al., 2014). The bacterial suspension was centrifuged at $5000 \mathrm{rpm}$, at $4{ }^{0} \mathrm{C}$ for 
14010 minutes. The supernatant was extracted with ethyl acetate. The bacterial pellet was extracted

141 with methanol. The ratio of solvent to culture was 1:1 (v/v) (Kontiza et al., 2008). Ethyl acetate

142 and methanol fractions were evaporated, the mass was determined and the crude extracts were

143 kept at $-20^{\circ} \mathrm{C}$.

144 Antibacterial assay. The antibacterial activity was evaluated using the Disc Diffusion Method

145 (Montalvão et al., 2014), according to the Clinical and Laboratory Standards Institute (CLSI,

146 2017). S. aureus was streaked on to Muller-Hinton agar medium (Sigma-Aldrich) with the total

147 amount of standard ( $0.5 \mathrm{Mc}$ Farland). The paper disk ( $\phi 6 \mathrm{~mm}$; Advantec. Japan) containing 15

$148 \mu 1$ of crude extract was placed on the surface of the agar plate culture. The concentrations of

149 crude extract were $50 \mu \mathrm{g} / \mathrm{ml}, 250 \mu \mathrm{g} / \mathrm{ml}, 500 \mu \mathrm{g} / \mathrm{ml}$ and $1000 \mu \mathrm{g} / \mathrm{ml}$. Ethyl acetate and methanol

150 were used as negative control. Vancomycin was chosen as positive control (Sigma-Aldrich). The

151 culture plates were incubated overnight at $37^{\circ} \mathrm{C}$. Active isolates were shown by the clear zone

152 around the disk (Redwan et al., 2016).

153 PCR (Polymerase Chain Reaction) amplification. DNA extraction was done by chelex method

154 (de Lamballerie et al., 1992). This method is a modification used for marine bacteria (Lee et al.,

155 2003). The DNA template was used for PCR amplification. The primers selected to amplify the

156 16S rRNA gene segment were: 27f (5'-AGAGTTT-GATCMTGGCTCAG-3') and 1492r (5'-

157 TACGGY-TACCTTGTTACGACTT-3') (Weisburg et al., 1991). The PCR mixture contained

158 GoTaq ${ }^{\circledR G r e e n}$ Master Mix Promega $(12.5 \mu \mathrm{l})$, primer $27 \mathrm{~F}(1 \mu \mathrm{l})$, primer $1492 \mathrm{R}(1 \mu \mathrm{l})$,

159 template DNA $(1 \mu \mathrm{l})$ and $\mathrm{ddH} 2 \mathrm{O}(9.5 \mu \mathrm{l})$, so that the total volume was $25 \mu 1$. The primer

160 concentration was $10 \mathrm{pmol} / \mu \mathrm{L}$. PCR condition was following by denaturation at $95^{\circ} \mathrm{C}$ for 3

161 minutes, annealing at $53,9{ }^{\circ} \mathrm{C}$ for 1 minute, extension $72{ }^{\circ} \mathrm{C}$ for 1 minute for 30 cycles. The PCR

162 products were examined using $1 \%$ agarose gel electrophoresis and the result was visualized by 
163 using UVIDoc HD5 (UVITEC Cambridge).

164 DNA sequencing and phylogenetic analysis. DNA sequencing was carried out in the PT.

165 Genetica Science (Jakarta, Indonesia). The gene sequences were analyzed using Basic Local

166 Alignment Search Tool (BLAST) (Altschul et al., 1997). To identify different species,

167 phylogenetic trees were constructed using MEGA 7 with the 1000x bootstrap test. The results of

168 BLAST Homology were deposited to the DNA Data Bank of Japan (DDBJ, www.ddbj.nig.ac.jp)

169 in order to obtain the accession number.

170 Cells and Viruses. African green monkey kidney cells (Vero cell line $\mathrm{n}^{0}$ ATCC zccl81) were

171 grown in Eagle's minimum essential medium (MEM, Laboratory Eurobio) supplemented with

$1728 \%$ fetal calf serum (FCS), to which was added $1 \%$ of PCS (penicillin 10,000 IU/ml, colimycin

$17325,000 \mathrm{IU} / \mathrm{ml}$, streptomycin $10 \mathrm{mg} / \mathrm{ml}$; Sigma). Cells were routinely passaged every 3 days.

174 A virus stock of Herpes simplex virus type 1, wild 27 strain $\mathrm{ACV}^{\mathrm{s}} \mathrm{PFA}^{\mathrm{s}}$ was obtained from

175 Pr. Henri Agut, Laboratoire de Virologie de la Pitié Salpêtrière, Paris, France. Virus stock was

176 prepared by incubating Vero monolayers $\left(75 \mathrm{~cm}^{2}\right.$ culture flasks seeded with $3,5 \times 10^{5}$ cells $\left./ \mathrm{ml}\right)$ at

177 low multiplicity and incubating at $37{ }^{\circ} \mathrm{C}$, in a $95 \%$ air, $5 \% \mathrm{CO}_{2}(\mathrm{v}, \mathrm{v})$ atmosphere. Three days

178 after infection, the cultures were frozen and thawed twice, before clearing the preparation by

179 centrifugation at a low speed to remove cell debris. The resulting supernatant aliquot was stored

180 at $-70{ }^{\circ} \mathrm{C}$ until used. Virus titrations were performed by the Red and Muench dilution method,

181 using 10 wells on 96-wells microtiter plates per dilution. The virus titre was estimated from

182 cytopathogenicity and expressed as $50 \%$ infectious doses per millilitre $\left(\mathrm{ID}_{50} / \mathrm{ml}\right)$.

183 Cytotoxicity and antiviral test. Using the Vero cell/HSV-1 model, $100 \mu 1$ of cellular suspension

$184\left(3,5 \times 10^{5}\right.$ cells $\left./ \mathrm{ml}\right)$ in Eagle's MEM containing 8\% FCS and dilution of potential extract (NP31-

185 01, KJB-07) at concentration 5-1000 $\mu \mathrm{g} / \mathrm{ml}$ in Eagle's MEM with a total volume of $200 \mu 1$ were 
186 grown in 96 well plates. Vero cells were placed in Eagle's MEM with a final volume of $200 \mu 1$ in

187 each well and were used as positive controls. The well plates were incubated at $37{ }^{\circ} \mathrm{C}$ for 72

188 hours. Cytotoxic activity was observed by microscope and cells were tested using the neutral red

189 dye method. Optical density was measured at $540 \mathrm{~nm}$ using a spectrophotometer

190 (SpectraCountTM, France, Packard). The 50\% cytotoxic concentration $\left(\mathrm{CC}_{50}\right)$ of the test

191 compound was defined as the concentration that reduced the absorbance of mock-infected cells

192 to $50 \%$ of that of controls. $\mathrm{CC}_{50}$ values were determined as the percentage of destruction $(\% \mathrm{D})$ :

$\left.193\left[\left(\mathrm{OD}_{\mathrm{c}}\right) \mathrm{C}-\mathrm{OD}_{\mathrm{c}}\right) \mathrm{MOCK} /\left(\mathrm{OD}_{\mathrm{c}}\right) \mathrm{C}\right] \times 100 .\left(\mathrm{OD}_{\mathrm{c}}\right) \mathrm{C}-\left(\mathrm{OD}_{\mathrm{c}}\right) \mathrm{MOCK}$ were the OD values of the

194 untreated cells and treated cells (Langlois et al., 1986).

195 A serial dilution of the extracts was prepared in MEM media, $50 \mu 1$ of extract, $50 \mu 1$ MEM

196 and $100 \mu \mathrm{l}$ of cellular suspension $\left(3,5 \times 10^{5}\right.$ cells $\left./ \mathrm{ml}\right)$ infected with HSV-1 at a multiplicity of

197 infection (MOI) of $0.001 \mathrm{ID}_{50} / \mathrm{ml}$ were added in 96 well plates. Acyclovir (9-(2-

198 hydroxyethoxymethyl) was used as a control positive against HSV-1 ranging from $0.05-5$

$199 \mu \mathrm{g} / \mathrm{ml}$. Cultures were grown in incubation at $37^{\circ} \mathrm{C}$ for 72 hours in a humidified $\mathrm{CO}_{2}$ atmosphere

$200\left(5 \% \mathrm{CO}_{2}\right)$. Antiviral activity was observed by microscope and cells were tested using the neutral

201 red dye method. The protection of the extract from virus-infected cells was expressed by $50 \%$

202 effective antiviral extract concentration $\left(\mathrm{EC}_{50}\right)$. OD was measured at $540 \mathrm{~nm}$. The OD was

203 related directly to the percentage of viable cells, which was inversely related to the cytopathic

204 effect $(\mathrm{CPE}) . \mathrm{EC}_{50}$ values were determined as the percentage of cell protection $(\% \mathrm{P})$ : $\left[\left(\mathrm{OD}_{\mathrm{t}}\right.\right.$ virus

$205-\mathrm{OD}_{\mathrm{c}}$ virus $) /\left(\mathrm{OD}_{\mathrm{c}} \mathrm{MOCK}-\mathrm{OD}_{\mathrm{c}}\right.$ virus $\left.)\right] \mathrm{x} 100 . \mathrm{OD}_{\mathrm{c}}$ and $\mathrm{OD}_{\mathrm{t}}$ were the $\mathrm{OD}$ values of the virus

206 control and test sample, $\mathrm{OD}_{\mathrm{c}} \mathrm{MOCK}$ was the OD of mock-infected control (Langlois et al.,

207 1986). Interpretation of the data was presented using a system of linear regression equations. 
208 TLC Direct-bio autography and LC-MS/MS analysis. The compounds were analyzed using

209 Thin Layer Chromatography (TLC) with silica gel on aluminum sheets (20x20 cm) $\left.\mathrm{F}_{254} \mathrm{KgaA}\right)$.

210 Gradient: hexane and ethyl acetate (7:3, 1:1, 3:7). Compound bands were detected by UV

211 absorbance and fluorescence. The compounds were characterized by LCMS/MS (Choma and

212 Jesionek, 2015). LC-MS/MS analyses were done on a UNIFI chromatographic instrument, with

213 an acquity UPLC ${ }^{\circledR}$ HSS T3 $1.8 \mu(2.1 \times 100 \mathrm{~mm})$ column. Mobile phase A was $0.1 \%$ formic

$214 \mathrm{acid} /$ water and mobile phase $\mathrm{B}$ was acetonitrile +0.1 formic acid with gradient $\mathrm{A} / \mathrm{B}=95 / 5$, $21560 / 40,0 / 100$ and $95 / 5$ in 10 minutes.

\section{3. Results}

218 Nudibranchs identification. Nudibranchs are widely spread in the seas around the world, 219 especially in Indonesia (http://www.marinespecies.org/imis.php?persid=7211). Fifteen

220 nudibranchs species were collected from the National Park of Karimunjawa, Jepara and five

221 from Bali. Several nudibranchs have been found on various basic substrates as shown in Table 1.

222 Most of them feed on sponges, tunicates, hydroids and bryozoans (Avila, 2006). The species 223 were identified based on colour, shape of the body and surface texture of the body as shown in 224 Table 1 (Behrens, 2005)(Coleman, 2001). The identification results showed that 20 nudibranch 225 species collected from Karimunjawa and Bali seawaters belonged to four genera, three 226 nudibranch Phyllidiidae, Chromodorididae, Flabellinidae and Plankobranchidae (Sacoglossa)

227 (Table 1). Examples are shown in figure 1.

228 Isolation of symbiont bacteria. Preliminary isolation of bacterial symbionts from the surface and 229 the viscera of nudibranchs (figure 2) were determined by the growth of bacteria in Zobell 2216E 230 agar media. The numbers of isolates were determined and are presented in Table 1. 
231 Anti-MRSA screening and crude extract assay. The results of the antibacterial activity are

232 presented in Figure 3. There is one active symbiont isolate of Phyllidia coelestis (KJB-07) from

233 Karimunjawa and one active symbiont isolate of Phyllidia varicosa (NP31-01) from Bali. The

234 strain KJB-07 has stronger activity than the strain NP31-01 based on the diameter of the clear

235 zone. The total mass of crude extract from supernatant of KJB-07 and NP31-01 was $1 \mathrm{~g} / 3 \mathrm{~L}$. The

236 ethyl acetate extract was found to be active against MRSA at concentrations of $500 \mu \mathrm{g} / \mathrm{ml}$ and

$2371000 \mu \mathrm{g} / \mathrm{ml}$ as shown in Table 2. The methanol extract from the bacterial pellet was found to be

238 inactive against MRSA.

239 DNA sequencing and phylogenetic tree. The complete 16S rDNA sequences of strain NP31-01

240 (1400 bp) and strain KJB-07 (1376 bp) were obtained. The sequence homology of 99\% in

241 phylogenetic tree showed that the strain KJB-07 from Phyllidia coelestis was closely related to

242 that of Pseudoalteromonas rubra (Figure 4) and the strain NP31-01 from Phyllidia varicosa was

243 closely related to Virgibacillus salarius (Figure 4). This sequence has been deposited to the

244 Genbank. The sequences have received the accession number LC328972.1 and MH016561.

245 Cytotoxic and antiviral activity. After three days of treatment, microscopically visible alteration

246 of normal cell morphology was observed and the viability assay showed destruction of a cell

247 layer for extract from Pseudoalteromonas rubra. This extract was cytotoxic on the Vero cell in

248 the entire range of concentration assayed $(5-1000 \mu \mathrm{g} / \mathrm{ml})$ as shown in table 3 . At concentrations

249 of $1000 \mu \mathrm{g} / \mathrm{ml}, 71 \%$ of cell destruction was observed. At MOI $0.001 \mathrm{ID}_{50} /$ cells, no anti HSV-1

250 was performed after $72 \mathrm{~h}$.

251 The compounds from Virgibacillus salarius present no cytotoxicity in the entire range of

252 concentrations assayed $(5-1000 \mu \mathrm{g} / \mathrm{ml})$ as shown in table 3. At concentrations of $1000 \mu \mathrm{g} / \mathrm{ml}$

253 only $10 \%$ of cell destruction was shown but no anti HSV-1 was present. 
254 TLC and $\mathbf{L C}$-MS $/ \mathbf{M S}$ data. The results showed that the three compounds were well separated on

255 Thin Layer Chromatography (Figure 5). Of the three compounds produced by P. rubra in LC-

256 MS/MS (Figure 6), compound 1, prodigiosin showed ions at $\mathrm{m} / \mathrm{z}$ 324.29; compound 2,

257 stearidonic acid showed ions at $\mathrm{m} / \mathrm{z}$ 277.21; and compound 3, (22E,24R)-5 $\alpha 8 \alpha$-Epidioxyergosta-

258 6,9,22-trien-3 $\beta$-ol showed ions at $m / z$ 449.31. The chemical structures are given in Table 4.

\section{Discussion}

261 In this paper, we present the first study on anti-MRSA, cytotoxicity, and antiviral activities

262 from crude extracts of symbiotic bacteria in the Heterobranchia. Nudibranchs, are one of many

263 marine invertebrate groups that feed on marine sponges, a surce of bioactive compounds. The

264 bioactive compounds found in nudibranchs are greatly influenced by food and symbiotic bacteria

265 (Fisch et al., 2017). Nudibranchs have a wide variety of bacteria that are affected by location and

266 food. In previous studies, the different habitats and conditions have been shown to affect the

267 biodiversity of symbiotic bacteria and bioactive compounds (Zhukova, 2014). We found different

268 activities of two potential symbiotic bacteria of nudibranchs from the two locations studied.

269 Many species we found in Karimunjawa are from the same family, the Phyllididae, whereas in

270 Bali a wide range of species was found from different families. Previous work reported that

271 Phyllididae commonly produced new sesquiterpenoid isonitriles and several other bioactive

272 compounds (Fisch et al., 2017)(Sim et al., 2017). We report here that symbiotic bacteria from the

273 family of Phyllidiidae have potential anti-MRSA and cytotoxicity activity.

274 Earlier studies were limited by the fact that entire animals were used for isolation of extract

275 (Dewi et al., 2016)(Sim et al., 2017)(Zhukova, 2014). In contrast, we cultured the symbiont

276 bacteria that produce the active compounds, allowing us to produce large amounts of extract, 
277 while conserving the marine environment by using only a very limited number of animals.

278 We isolated bacteria from the body surface and internal organs of nudibranchs known as

279 viscera. We have identified two bacteria species, which show potential anti-MRSA activity.

280 In previous studies, bacteria have been successfully isolated from the epithelial cells of the

281 notum, the mantle edge and vestibular gland (Klussmann-Kolb and Brodie, 1999)(Zhukova and

282 Eliseikina, 2012). It has been suggested that the bacteria may play a role in protection or defense

283 from predators (Fajardo et al., 2014), however, the specific function of these bacteria is still

284 under discussion. No molecular identification of bacteria has been reported to date. In the

285 screening effort of our studies, we have identified the symbiotic bacteria as capable of producing

286 anti-MRSA compounds by the complete sequences of the 16S rRNA gene. Two bacterial isolates

287 were found to have 99\% sequence identity with Pseudoalteromonas rubra (KJB-07) and

288 Virgibacillus salarius (NP31-01), respectively. Previous work reported that P. rubra, that had

289 been successfully isolated from a small piece of marine sponge (Mycale armata) producing red

290 pigment, had antibacterial activity (Fehér et al., 2008). Our study is comparable with previous

291 research, in which a novel phenolic anti-MRSA compound from Pseudoalteromonas phenolic

292 was isolated from sea water (Isnansetyo and Kamei, 2003). Another study on anti-MRSA has

293 been explored in other bacterial symbionts of marine organisms such as Tunicata, Porifera, and

294 marine algae (Fedders et al., 2010)(Kamei and Isnansetyo, 2003)(Hentschel et al., 2001). No

295 research on anti-MRSA activity of the symbiotic bacteria of nudibranchs has been reported

296 previously.

297 To evaluate the anti-bacterial activity, we showed that the ethyl acetate extract of the

298 supernatant of the bacteria caused an inhibition zone in MRSA cultures as indicated in Table 2,

299 whereas the methanol extract of the centrifuged bacteria showed no activity. The ethyl acetate 
extract showed that anti-MRSA activity of $P$. rubra was higher than $V$. salarius at concentrations

301

302

303

304

305

306

307

308

309

310

311

of $500-1000 \mu \mathrm{g} / \mathrm{ml}$. The diameter of an inhibition zone of $V$. salarius was $7.18 \mathrm{~mm}$ at a

concentration of $500 \mu \mathrm{g} / \mathrm{ml}$ and increased to $8.26 \mathrm{~mm}$ at concentration $1000 \mu \mathrm{g} / \mathrm{ml}$. Thehe inhibition zone of P. rubra increased from $8.15-9.23 \mathrm{~mm}$ at concentrations of $500-1000$

$\mu \mathrm{g} / \mathrm{ml}$. The anti-MRSA activity of crude extract was comparable with Vancomycin in that the antibiotic had higher inhibition zone in $15 \mathrm{~mm}$ at concentrations of $30 \mu \mathrm{g} / \mathrm{ml}$.

Table 2 shows that the two extracts had different effects on the MRSA. In this research, $P$. rubra as a gram-negative bacteria had cell walls that were thinner than $V$. salarius as grampositive. Pseudoalteromonas rubra was able to prevent the loss of intracellular proteins, and reduced access of hydrolytic enzymes and some compounds produced by S. aureus (Pinto et al., 2017). Extract from $P$. rubra had a stronger activity than from $V$. salarius. Recent studies reported that the ethyl acetate extract from Pseudomonas sp. was able to produce the compound 1 -acetyl-beta-carboline, which is active against MRSA at concentrations of 32-128 $\mu \mathrm{g} / \mathrm{ml}$ (Lee et al., 2013). Isnansetyo, et. al., showed bactericidal and bacteriolytic activity of 2,4diacetylphloroglucinol (DAPG) produced by Pseudomonas sp. against MRSA and VRSA (Isnansetyo et al., 2003). The mechanisms of resistance affected the activity of DAPG. The activity of compounds produced by marine bacteria should be explored and evaluated. The cytotoxicity in the P. rubra extract on Vero cells was directly proportional to the increase in the concentration of the extract. This may be due to production of endotoxins. We analyzed by LCMS to identified the cytotoxic effect of the P. rubra extract is due to the same compound that is active against the MRSA or not.

The $V$. salarius extracts had no cytotoxic effect at any of the concentrations tested.

Virgibacillus sp. has been known as non-cytotoxic and to be a potential source of new 
323 polysaccharide bioflocculant (Cosa et al., 2011). Cell wall of $V$. salarius contained meso-

324 diaminopimelic acid as a major component that has been suggested to correspond to the non-

325 cytotoxicity active compounds against MRSA and (Hua et al., 2008). Previous work reported the

326 mechanisms of bacteria associated marine organisms, which are bacteria associated with ascidian

327 Cystodytes dellechiajei (Martínez-García et al., 2007) and marine flatworms (Lin et al., 2017).

328 García, M.M., et. al., reported the role of the bacterial community associated with C. dellechiajei

329 in production of Pyridoacidine alkaloids. This research evaluated that antiproliferative activities

330 are found in the host and the associated bacteria but the cytotoxic activities are only found in the

331 associated bacteria. The research indicated that the associated bacteria transformed the

332 compounds and it could be toxic due to environmental influences. The crude extract from

333 bacteria associated with the marine flatworm had potential anti-MRSA and toxic activity against

334 Hela-cells. Further study is necessary to separate and identify the active and cytotoxic

335 compound.

336 Recent studies have demonstrated the importance of antiviral compounds from marine

337 invertebrate; such as Phyllocaulis boraceiensis, which contains polyunsaturated fatty acids that

338 disturb the virus envelope (Toledo-Piza et al., 2016). Manzamine A from sponge genus

339 Acanthostrongylophora, worked by inhibiting viral replication (Palem et al., 2011). In our study,

340 crude extracts of P. rubra and V. salarius showed no activity against HSV-1.

341 We identified three compounds from P. rubra, that showed anti MRSA activity and also

342 cytotoxic activity (table 4). These compounds, prodigiosin, stearidonic acid and (22E,24R)-

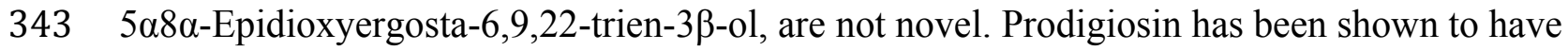

344 antibacterial and cytotoxic activity (Francisco et al., 2007). Another study has shown that

345 steridonic acid had synergism with amphotericin-B in inhibiting Candida (Taitt, 2012). The 
346 compound (22E,24R)-5 $\alpha 8 \alpha$-Epidioxyergosta-6,9,22-trien-3 $\beta$-ol has been found previously in

347 Hypsizigus marmoreus (Xu et al., 2007) and in the South-East Asian mushroom Amanita

348 subjunquillea (Kim et al., 2008). This compound has been shown to have moderate toxicity

349 against human tumor cells.

350

\section{5. Conclusions:}

352 This is the first reported study describing research on anti-MRSA, cytotoxicity and anti HSV-1

353 activity of bacterial symbionts from viscera of nudibranchs. We showed that crude extracts from

354 culture supernatants of Pseudoalteromonas rubra and Virgibacillus salarius, symbionts of these

355 nudibranchs, have anti-MRSA activity, which must be caused by compounds that are produced

356 and secreted by the bacteria. Extracts from $P$. rubra showed cytotoxic effects on Vero cells,

357 whereas extracts from $V$. salarius did not show cytotoxic effects. No anti HSV-1 activity was

358 detected in any of the bacterial extracts. Three compounds were identified: prodigiosin,

359 stearidonic acid, and (22E,24R)-5 $\alpha 8 \alpha$-Epidioxyergosta-6,9,22-trien-3 $\beta$-ol. Prodigiosin and

360 stearidonic acid have been suggested to exhibit antibacterial activity; moreover epidioxyergosta

361 has been suggested to have cytotoxic activity.

362

363

6. Conflict of interest statement

We declare that we have no conflict of interest.

365

\section{Acknowledgments}

This work was supported by grants from the Directorate Research and Community

368 Services Ministry of Research Technology and Higher Education Jakarta, Indonesia, the 
370 mobility grant under sandwich-like program (1930/D3.2/PG/2017). The authors thank Kadek

371 Fendi Wirawan for help with collecting samples in Bali and thank to Research Center for

372 Chemistry, Indonesian Institute of Sciences (LIPI), PUSPITEK, Serpong 15314, Indonesia for 373 providing the LCMS/MS instrument.

374

375

376

377

378

379

380

381

382

383

384

385

386

387

388

389

390

391

392

\section{Author Contribution}

R.K. collected samples, conducted bioassays, performed all these experiments and prepared the manuscript; G.P., reviewed the manuscript and interpreted the results; G.B., A.S., O.K.R., N.B., and A.T., planned the experiments, supervised the experiments and reviewed the manuscript;

A.T., collected samples; I.W.M. identified the nudibranchs; L.T., and C.M. performed cytotoxicity assay; R.K., M.A.A., and D.A performed the bacteria isolation and interpreted the results; all authors have seen the final version of the manuscript and agree with the content.

9. References. O.K.R., . A.S., . J., . E.Z., 2007. Richness of Secondary Metabolite-Producing Marine Bacteria Associated with Sponge Haliclona sp. Int. J. Pharmacol. 3, 275-279. https://doi.org/10.3923/ijp.2007.275.279

Akhi, M.T., Ghotaslou, R., Alizadeh, N., Pirzadeh, T., Beheshtirouy, S., Memar, M.Y., 2017. High frequency of MRSA in surgical site infections and elevated vancomycin MIC. Wound Med. 17, 7-10. https://doi.org/10.1016/j.wndm.2017.01.002

Altschul, S.F., Madden, T.L., Schäffer, A.A., Zhang, J., Zhang, Z., Miller, W., Lipman, D.J., 1997. Gapped BLAST and PSI-BLAST: a new generation of protein database search programs. Nucleic Acids Res. 25, 3389-3402.

Anand, T.P., Bhat, A.W., Shouche, Y.S., Roy, U., Siddharth, J., Sarma, S.P., 2006. 
Antimicrobial activity of marine bacteria associated with sponges from the waters off the

394 coast of South East India. Microbiol. Res. 161, 252-262.

395 https://doi.org/10.1016/j.micres.2005.09.002

396

397

398

399

400

401

402

403

404

405

406

407

408

409

410

411

412

413

414 Coleman, N. 2001. Neville Coleman's Underwater Geographic Pty Ltd CAN 002043076 ABN 415

Avila, C., 2006. Molluscan Natural Products as Biological Models : Chemical Ecology , Histology, and Laboratory Culture. Prog. Mol. Subcell. Biol.

Behrens, D.W. 2005. Nudibranch Behaviour. New World Publications, INC. Jacksonville, Florida U.S.A.

Benkendorff, K., 2010. Molluscan biological and chemical diversity: secondary metabolites and medicinal resources produced by marine molluscs. Biol. Rev. 85, 757-775. https://doi.org/10.1111/j.1469-185X.2010.00124.x

Chand, S., Karuso, P., 2017. Isolation and total synthesis of two novel metabolites from the fissurellid mollusc Scutus antipodes. Tetrahedron Lett. 58, 1020-1023. https://doi.org/10.1016/j.tetlet.2017.01.096

Chen, H., Chen, G., Zheng, X., Guo, Y., 2019. Contribution of specific diseases and injuries to changes in health adjusted life expectancy in 187 countries from 1990 to 2013 : retrospective observational study $1-12$. https://doi.org/10.1136/bmj.1969

Choma, I.M., Jesionek, W., 2015. TLC-Direct Bioautography as a High Throughput Method for Detection of Antimicrobials in Plants 225-238. https://doi.org/10.3390/chromatography2020225

CLSI, 2017. Performance standards for antimicrobial susceptibility testing, Performance standards for antimicrobial susceptibility testing. 36002043 076. National Library of Australia. 
416 Cosa, S., Mabinya, L. V., Olaniran, A.O., Okoh, O.O., Bernard, K., Deyzel, S., Okoh, A.I., 2011.

417 Bioflocculant production by Virgibacillus sp. rob isolated from the bottom sediment of

418 algoa bay in the Eastern Cape, South Africa. Molecules 16, 2431-2442.

419 https://doi.org/10.3390/molecules16032431

420 de Lamballerie, X., Zandotti, C., Vignoli, C., Bollet, C., de Micco, P., 1992. A one-step

421 microbial DNA extraction method using \&quot; Chelex 100\&quot; suitable for gene

422 amplification. Res. Microbiol. 143, 785-90.

423 De Oliveira, J.H.H.L., Nascimento, A.M., Kossuga, M.H., Cavalcanti, B.C., Pessoa, C.O.,

424 Moraes, M.O., Macedo, M.L., Ferreira, A.G., Hajdu, E., Pinheiro, U.S., Berlinck, R.G.S.,

425 2007. Cytotoxic alkylpiperidine alkaloids from the Brazilian marine sponge Pachychalina

426 alcaloidifera. J. Nat. Prod. 70, 538-543. https://doi.org/10.1021/np060450q

427 Defer, D., Bourgougnon, N., Fleury, Y., 2009. Screening for antibacterial and antiviral activities

428 in three bivalve and two gastropod marine molluscs. Aquaculture 293, 1-7.

429 https://doi.org/10.1016/j.aquaculture.2009.03.047

430 Dewi, A.S., Cheney, K.L., Urquhart, H.H., Blanchfield, J.T., Garson, M.J., 2016. The

431 sequestration of oxy-polybrominated diphenyl ethers in the nudibranchs miamira magnifica

432 and miamira miamirana. Mar. Drugs 14. https://doi.org/10.3390/md14110198

433 Fajardo, P., Atanassova, M., Garrido-Maestu, A., Wortner-Smith, T., Cotterill, J., Cabado, A.G.,

434 2014. Bacteria isolated from shellfish digestive gland with antipathogenic activity as

435 candidates to increase the efficiency of shellfish depuration process. Food Control 46, 272-

436 281. https://doi.org/10.1016/j.foodcont.2014.05.038

437 Fedders, H., Podschun, R., Leippe, M., 2010. The antimicrobial peptide Ci-MAM-A24 is highly

438 active against multidrug-resistant and anaerobic bacteria pathogenic for humans. Int. J. 
440 Fehér, D., Barlow, R.S., Lorenzo, P.S., Hemscheidt, T.K., 2008. A 2-Substituted Prodiginine, 2-(

$441 \quad p$-Hydroxybenzyl)prodigiosin, from Pseudoalteromonas rubra. J. Nat. Prod. 71, 1970-

442 1972. https://doi.org/10.1021/np800493p

443 Fisch, K., Hertzer, C., Böhringer, N., Wuisan, Z., Schillo, D., Bara, R., Kaligis, F., Wägele, H., 444 König, G., Schäberle, T., 2017. The Potential of Indonesian Heterobranchs Found around 445 Bunaken Island for the Production of Bioactive Compounds, Marine Drugs. https://doi.org/10.3390/md15120384

447

448

449

450

451

452

453

454

455

456

457

458

459

460

461

Francisco, R., Pérez-Tomás, R., Gimènez-Bonafé, P., Soto-Cerrato, V., Giménez-Xavier, P., Ambrosio, S., 2007. Mechanisms of prodigiosin cytotoxicity in human neuroblastoma cell lines. Eur. J. Pharmacol. 572, 111-119. https://doi.org/10.1016/j.ejphar.2007.06.054

Gastropoda, M.H., Eisenbarth, J., Undap, N., Papu, A., Schillo, D., Dialao, J., Reumschüssel, S., Kaligis, F., Bara, R., Schäberle, T.F., König, G.M., Yonow, N., Wägele, H., 2018. Marine Heterobranchia (Gastropoda, Mollusca) in Bunaken National Park, North Sulawesi, Indonesia_A Follow-Up Diversity Study. https://doi.org/10.3390/d10040127

Guzmán-Blanco, M., Mejía, C., Isturiz, R., Alvarez, C., Bavestrello, L., Gotuzzo, E., Labarca, J., Luna, C.M., Rodríguez-Noriega, E., Salles, M.J.C., Zurita, J., Seas, C., 2009. Epidemiology of meticillin-resistant Staphylococcus aureus (MRSA) in Latin America. Int. J. Antimicrob. Agents 34, 304-308. https://doi.org/10.1016/j.ijantimicag.2009.06.005

He, W.F., Li, Y., Feng, M.T., Gavagnin, M., Mollo, E., Mao, S.C., Guo, Y.W., 2014. New isoquinolinequinone alkaloids from the South China Sea nudibranch Jorunna funebris and its possible sponge-prey Xestospongia sp. Fitoterapia 96, 109-114. https://doi.org/10.1016/j.fitote.2014.04.011 
462 Hentschel, U., Schmid, M., Wagner, M., Fieseler, L., Gernert, C., Hacker, J., 2001. Isolation and 463 phylogenetic analysis of bacteria with antimicrobial activities from the Mediterranean $464 \quad$ sponges Aplysina aerophoba and Aplysina cavernicola. FEMS Microbiol. Ecol. 35, 305465 312. https://doi.org/10.1111/j.1574-6941.2001.tb00816.x

466 Hua, N.P., Hamza-Chaffai, A., Vreeland, R.H., Isoda, H., Naganuma, T., 2008. Virgibacillus 467 salarius sp. nov., a halophilic bacterium isolated from a Saharan salt lake. Int. J. Syst. Evol. 468

469

470

471

472 Microbiol. 58, 2409-2414. https://doi.org/10.1099/ijs.0.65693-0

Isnansetyo, A., Cui, L., Hiramatsu, K., Kamei, Y., 2003. Antibacterial activity of 2,4diacetylphloroglucinol produced by Pseudomonas sp. AMSN isolated from a marine alga, against vancomycin-resistant Staphylococcus aureus. Int. J. Antimicrob. Agents 22, 545547. https://doi.org/10.1016/S0924-8579(03)00155-9

Isnansetyo, A., Kamei, Y., 2003. Pseudoalteromonas phenolica sp. nov., a novel marine bacterium that produces phenolic anti-methicillin-resistant Staphylococcus aureus substances. Int. J. Syst. Evol. Microbiol. 53, 583-588. https://doi.org/10.1099/ijs.0.02431-0

John Jimtha, C., Jishma, P., Sreelekha, S., Chithra, S., Radhakrishnan, E., 2017. Antifungal 477 properties of prodigiosin producing rhizospheric Serratia sp. Rhizosphere 3, 105-108. https://doi.org/10.1016/j.rhisph.2017.02.003

479

480

481

482

483

484

Kamei, Y., Isnansetyo, A., 2003. Lysis of methicillin-resistant Staphylococcus aureus by 2, 4diacetylphloroglucinol produced by Pseudomonas sp . AMSN isolated from a marine alga $21,71-74$.

Kim, K.H., Choi, S.U., Park, K.M., Seok, S.J., Lee, K.R., 2008. Cytotoxic Constituents of Amanita subjunquillea 31, 579-586. https://doi.org/10.1007/s12272-001-1196-3

Klussmann-Kolb, A., Brodie, G.D., 1999. Internal storage and production of symbiotic bacteria 
in the reproductive system of a tropical marine gastropod. Mar. Biol. 133, 443-447. https://doi.org/10.1007/s002270050483

487

488

489

490

491

492

493

494

495

496

497

498

499

500

501

502

503

504

505

506

507

Kontiza, I., Stavri, M., Zloh, M., Vagias, C., Gibbons, S., Roussis, V., 2008. New metabolites with antibacterial activity from the marine angiosperm Cymodocea nodosa. Tetrahedron 64, 1696-1702. https://doi.org/10.1016/J.TET.2007.12.007

Langlois, M., Allard, J.P., Nugier, F., Aymard, M., 1986. A rapid and automated colorimetric assay for evaluating the sensitivity of herpes simplex strains to antiviral drugs. J. Biol. Stand. 14, 201-211. https://doi.org/10.1016/0092-1157(86)90004-1

Lee, D.-S., Eom, S.-H., Jeong, S.-Y., Shin, H.J., Je, J.-Y., Lee, E.-W., Chung, Y.-H., Kim, Y.M., Kang, C.-K., Lee, M.-S., 2013. Anti-methicillin-resistant Staphylococcus aureus (MRSA) substance from the marine bacterium Pseudomonas sp. UJ-6. Environ. Toxicol. Pharmacol. 35, 171-7. https://doi.org/10.1016/j.etap.2012.11.011

Lee, Y.K., Kim, H.W., Liu, C.L., Lee, H.K., 2003. A simple method for DNA extraction from marine bacteria that produce extracellular materials. J. Microbiol. Methods 52, 245-50.

Lin, H.-N., Wang, K.-L., Wu, Z.-H., Tian, R.-M., Liu, G.-Z., Xu, Y., 2017. Biological and Chemical Diversity of Bacteria Associated with a Marine Flatworm. Mar. Drugs 15, 281. https://doi.org/10.3390/md15090281

Martínez-García, M., Díaz-Valdés, M., Ramos-Esplá, A., Salvador, N., Lopez, P., Larriba, E., Antón, J., 2007. Cytotoxicity of the ascidian Cystodytes dellechiajei against tumor cells and study of the involvement of associated microbiota in the production of cytotoxic compounds. Mar. Drugs 5, 52-70. https://doi.org/10.3390/md20070006

Mitterreiter, J.G., Titulaer, M.J., Nierop, G.P. Van, Van, J.J.A., 2016. Prevalence of Intrathecal Acyclovir Resistant Virus in Herpes Simplex Encephalitis Patients 1, 1-11. 
Montalvão, S.I.G.H.M., Singh, V., Haque, S., 2014. Bioassays for bioactivity screening, Comprehensive Analytical Chemistry. Elsevier B.V. https://doi.org/10.1016/B978-0-444-

512 No Title, 1981.

513 Palem, J.R., Bedadala, G.R., El Sayed, K.A., Hsia, S.C. V, 2011. Manzamine A as a novel 514 inhibitor of herpes simplex virus type-1 replication in cultured corneal cells. Planta Med.

Radjasa, O.K., Marterns, T., Grossart, H.P., Brinkhoff, T., Sabdono, A., Simon, M., 2007.

Pinto, N. de C.C., Campos, L.M., Evangelista, A.C.S., Lemos, A.S.O., Silva, T.P., Melo, R.C.N., 77, 46-51. https://doi.org/10.1055/s-0030-1250093

\section{Pinto, N. de C.C., Canpos, L.M., Evangelista, A.C.S., Lemos, A.S.O., Silva, T.P., Melo, R.C.N.,} de Lourenço, C.C., Salvador, M.J., Apolônio, A.C.M., Scio, E., Fabri, R.L., 2017.

Antimicrobial Annona muricata L. (soursop) extract targets the cell membranes of Grampositive and Gram-negative bacteria. Ind. Crops Prod. 107, 332-340.

https://doi.org/10.1016/j.indcrop.2017.05.054

Antagonistic activity of a marine bacterium Pseudoalteromonas luteoviolacea TAB4.2

associated with coral Acropora sp. J. Biol. Sci. 7, 239-246.

https://doi.org/10.3923/jbs.2007.239.246

Radjasa, O.K., Vaske, Y.M., Navarro, G., Vervoort, H.C., Tenney, K., Linington, R.G., Crews, P., 2011. Highlights of marine invertebrate-derived biosynthetic products: Their biomedical potential and possible production by microbial associants. Bioorganic Med. Chem. 19, 6658-6674. https://doi.org/10.1016/j.bmc.2011.07.017

529 Redwan, E.M., El-Baky, N.A., Al-Hejin, A.M., Baeshen, M.N., Almehdar, H.A., Elsaway, A., 530 Gomaa, A.-B.M., Al-Masaudi, S.B., Al-Fassi, F.A., AbuZeid, I.E., Uversky, V.N., 2016. 
Significant antibacterial activity and synergistic effects of camel lactoferrin with antibiotics

532 against methicillin-resistant Staphylococcus aureus (MRSA). Res. Microbiol. 167, 480-491. https://doi.org/10.1016/j.resmic.2016.04.006

534

Sabdono, A., Sawonua, P.H., Kartika, A.G.D., Amelia, J.M., Radjasa, O.K., 2015. Coral

Sassi, A. Ben, Harzallah-Skhiri, F., Bourgougnon, N., Aouni, M., 2008. Antiviral activity of some Tunisian medicinal plants against Herpes simplex virus type 1. Nat. Prod. Res. 22, 53-65. https://doi.org/10.1080/14786410701589790

Seyed Vahid Shetab-Boushehri, M.A., 2012. International Journal of Pharmacology.

541 Sim, D.C.-M., Wayan Mudianta, I., White, A.M., Martiningsih, N.W., Loh, J.J.M., Cheney,

542 K.L., Garson, M.J., 2017. New sesquiterpenoid isonitriles from three species of phyllidid 543 nudibranchs. Fitoterapia in press, 1-5. https://doi.org/10.1016/j.fitote.2017.10.003

544 Singh, S., Prasad, P., Subramani, R., Aalbersberg, W., 2014. Production and purification of a 545 bioactive substance against multi-drug resistant human pathogens from the marine-sponge546 derived Salinispora sp. Asian Pac. J. Trop. Biomed. 4, 825-831.

547 https://doi.org/10.12980/APJTB.4.2014C1154

548 Taitt, C.R., 2012. Stearidonic acid acts in synergism with amphotericin B in 40, 284-285.

549 https://doi.org/10.1016/j.ijantimicag.2012.05.019

550 Toledo-Piza, A.R. de, Figueiredo, C.A., Oliveira, M.I. de, Negri, G., Namiyama, G., Tonelotto, 551 M., Villar, K. de S., Rofatto, H.K., Mendonça, R.Z., 2016. The antiviral effect of mollusk 552 mucus on measles virus. Antiviral Res. 134, 172-181.

553 https://doi.org/10.1016/j.antiviral.2016.09.005 
554 Wakimoto, T., Tan, K.C., Abe, I., 2013. Ergot alkaloid from the sea slug Pleurobranchus

555 forskalii. Toxicon 72, 1-4. https://doi.org/10.1016/j.toxicon.2013.05.021

556 Wei, X., Xu, J., Yang, J., Liu, X., Zhang, R., Wang, W., Yang, J., 2015. Involvement of a Serpin 557 serine protease inhibitor (OoSerpin) from mollusc Octopus ocellatus in antibacterial 558 response. Fish Shellfish Immunol. 42, 79-87. https://doi.org/10.1016/j.fsi.2014.10.028

559 Weisburg, W.G., Barns, S.M., Pelletier, D.A., Lane, D.J., 1991. 16S ribosomal DNA

560 amplification for phylogenetic study. Weisburg, WG 173, 697-703.

561 Xu, M., Choi, J., Jeong, B., Li, G., Lee, K., Lee, C., Woo, M., Lee, E.S., Jahng, Y., Chang, H., 562 Lee, S., Son, J., 2007. Cytotoxic Constituents Isolated from the Fruit Bodies of Hypsizigus 563 marmoreus 30, 28-33.

564 Zhukova, N. V., 2014. Lipids and fatty acids of nudibranch mollusks: Potential sources of 565 bioactive compounds. Mar. Drugs 12, 4578-4592. https://doi.org/10.3390/md12084578

566 Zhukova, N. V., Eliseikina, M.G., 2012. Symbiotic bacteria in the nudibranch mollusk

567 Dendrodoris nigra: Fatty acid composition and ultrastructure analysis. Mar. Biol. 159, 568 1783-1794. https://doi.org/10.1007/s00227-012-1969-7

569

570 


\section{Table $\mathbf{1}$ (on next page)}

Samples collected and total number of symbiont bacteria in Nudibranch.

The table show about morphology identification of nudibranch 
1 Table 1. Samples collected and total number of symbiont bacteria in Nudibranch.

\begin{tabular}{|c|c|c|c|c|c|c|}
\hline $\begin{array}{l}\text { Spesies } \\
\text { Code }\end{array}$ & $\begin{array}{l}\text { Nudibranch } \\
\text { Species }\end{array}$ & Appearance of the Opisthobranch & $\begin{array}{l}\text { Number of } \\
\text { Isolates of } \\
\text { Bacteria }\end{array}$ & $\begin{array}{l}\text { Depth } \\
\text { (m) }\end{array}$ & Substrate & Locality \\
\hline NT1-162 & Hypselodoris whitei & $\begin{array}{l}\text { Whitish background colour with reddish purple longitudinal lines covering the mantle. The rhinophores are orange to } \\
\text { orange-red with a distinctive white tip. The gills are similarly coloured with white on the inside and usually at the tip } \\
\text { of each gill. }\end{array}$ & 10 & 19 & Sand & Bali \\
\hline NT1-164 & Hypselodoris infucata & $\begin{array}{l}\text { Grey mantle with yellow and purple spots spread on the surface. The rhinophores are red and the gills composed by } \\
\text { two-dimensional leaf with a red line along the internal and external edge. }\end{array}$ & 11 & 15 & Hydroid & Bali \\
\hline NP31-04 & $\begin{array}{l}\text { Goniobranchus } \\
\text { leopardus }\end{array}$ & $\begin{array}{l}\text { The mantle consists of purple-brown marks, ringed with reticulate brownish background, and a purple border. There } \\
\text { are four colour bands around the mantle edge, an outermost white, then translucent greyish purple, then white, then } \\
\text { yellow. }\end{array}$ & 12 & 18 & Coral & Bali \\
\hline NP31-01 & Phyllidia varicosa & $\begin{array}{l}\text { The mantle consists of longitudinal, tuberculate notal ridges. The ridge and bases of the tubercles are blue-grey } \\
\text { in colour and the tubercles are capped in yellow. }\end{array}$ & 10 & 15 & Coral & Bali \\
\hline KJN-17 & Phyllidia ocellata & The dorsal pattern consists of series of white tubercles, dark background and yellow rims. & 19 & 15 & Hydroid & Karimunjawa \\
\hline KJN-09 & Phyllidia varicosa & $\begin{array}{l}\text { The mantle consists of longitudinal, tuberculate notal ridges. The ridge and bases of the tubercles are blue-grey in } \\
\text { colour and the tubercles are capped in yellow. }\end{array}$ & 19 & 15 & Sand & Karimunjawa \\
\hline KJT-02 & Caloria indica & The body is full of white cerata and the horns are white with few purple rings spread along the axes. & 10 & 15 & Sponge & Karimunjawa \\
\hline KJN-13 & Phyllidiella nigra & The black background mantle is ornamented by white clustered tubercles. & 12 & 17 & Hydroid & Karimunjawa \\
\hline KJB-07 & Phyllidia coelestis & Black background mantle with blue-grey ridges; yellow-capped mid- dorsal tubercles. & 18 & 15 & Coral & Karimunjawa \\
\hline KJN-08 & Phyllidia varicosa & $\begin{array}{l}\text { The mantle consists of longitudinal, tuberculation total ridges. The ridge and bases of the tubercles are blue-grey in } \\
\text { colour and the tubercles are capped in yellow. }\end{array}$ & 19 & 15 & Sponge & Karimunjawa \\
\hline
\end{tabular}




\begin{tabular}{|c|c|c|c|c|c|c|}
\hline KJN-19 & Phyllidiella striata & White clustered tubercles and few yellow caps; black background dorsal. & 8 & 15 & Coral & Karimunjawa \\
\hline KJN-47 & Phyllidia varicosa & $\begin{array}{l}\text { The mantle consists of longitudinal, tuberculate notal ridges. The ridge and bases of the tubercles are blue-grey in } \\
\text { colour and the tubercles are capped in yellow. }\end{array}$ & 12 & 16 & Sponge & Karimunjawa \\
\hline KJN-46 & Phyllidia varicosa & $\begin{array}{l}\text { The mantle consists of longitudinal, tuberculate notal ridges. The ridge and bases of the tubercles are blue-grey in } \\
\text { colour and the tubercles are capped in yellow. }\end{array}$ & 11 & 18 & Tunicata & Karimunjawa \\
\hline KJN-48 & $\begin{array}{l}\text { Phyllidiopsis } \\
\text { shireenae }\end{array}$ & White dorsal with white tubercles; two longitudinal black lines. & 11 & 14 & Sponge & Karimnujawa \\
\hline KJN-42 & Goniobranchus kuniei & $\begin{array}{l}\text { They all have large purple or purple-brown spots or marks, usually ringed with white, brownish background, and a } \\
\text { purple border. }\end{array}$ & 12 & 16 & Coral & Karimunjawa \\
\hline KJN-44 & $\begin{array}{l}\text { Phyllidiella } \\
\text { cooraburrama }\end{array}$ & Extremely large, isolated, notal tubercles and black dorsal background. & 10 & 18 & Coral & Karimunjawa \\
\hline KJN-5 & $\begin{array}{l}\text { Phyllidiopsis } \\
\text { shireenae }\end{array}$ & White dorsal with white tubercles; two longitudinal black lines. & 8 & 15 & Bryozoa & Karimunjawa \\
\hline KJN-45 & Phyllidiopsis pipeki & The rhinophores are pink with a black tip, black lines extending from pale brown mantle edges. & 10 & 15 & Coral & Karimunjawa \\
\hline
\end{tabular}

2 
Table 2 (on next page)

Anti-MRSA activity (overlay, extract, antibiotic) 
1 Table 2. Anti-MRSA activity (overlay, extract, antibiotic)

\begin{tabular}{lcccccc}
\hline Crude extract & Concentration & \multicolumn{5}{c}{ Diameter of Clear Zone (mm) of Anti-MRSA } \\
\cline { 3 - 7 } & $(\mu \mathrm{g} / \mathbf{m l})$ & KJB-07 & NP31-01 & KJB-07 & NP31-01 & Vancomycin \\
& 50 & - & - & - & - & $\mathrm{nt}$ \\
Bacterial pellet & 250 & - & - & - & - & $\mathrm{nt}$ \\
(Methanol) & 500 & - & - & - & - & $\mathrm{nt}$ \\
& 1000 & - & - & - & - & $\mathrm{nt}$ \\
Supernatant & 50 & - & - & - & - & $\mathrm{nt}$ \\
(Ethyl acetate) & 250 & - & - & - & - & $\mathrm{nt}$ \\
& 500 & + & + & 8.15 & 7.18 & $\mathrm{nt}$ \\
Vancomycin & 1000 & + & + & 9.23 & 8.26 & $\mathrm{nt}$ \\
\hline
\end{tabular}

2 
Table 3 (on next page)

Evaluation ofcytotoxic and anti-HSV-1 activity of ethyl acetate extract of supernatant from $P$. rubra and $V$. salarius 
1 Table 3. Evaluation of cytotoxic and anti-HSV-1 activity of ethyl acetate extract of supernatant from P. rubra and 2 V. salarius

\begin{tabular}{ccc}
\hline $\begin{array}{c}\text { Extract of Bacteria } \\
\text { species }\end{array}$ & $\begin{array}{c}\mathbf{C C}_{50} \\
(\mu \mathrm{g} / \mathrm{ml})\end{array}$ & $\begin{array}{c}\mathbf{E C}_{50} \\
(\mu \mathrm{g} / \mathrm{ml})\end{array}$ \\
\hline $\begin{array}{cc}\text { Pseudoalteromonas rubra } \\
\text { Virgibacillus salarius }\end{array}$ & 75 & - \\
Acyclovir & $>1000$ & - \\
\hline
\end{tabular}

3 
Table 4 (on next page)

Identification of compound in P. rubra 
1 Table 4. Identification of compound in P. rubra

\begin{tabular}{lll}
\hline Compound name & Observed RT \\
\hline Compound 1. prodigiosin & 6.04 \\
Compound 2. stearidonic acid & 5.26 \\
Compidioxyergosta-6,9,22-trien- &
\end{tabular}

2

3 


\section{Figure 1}

Underwater photographs of the nudibranch; (A) Phyllidia varicosa from Bali

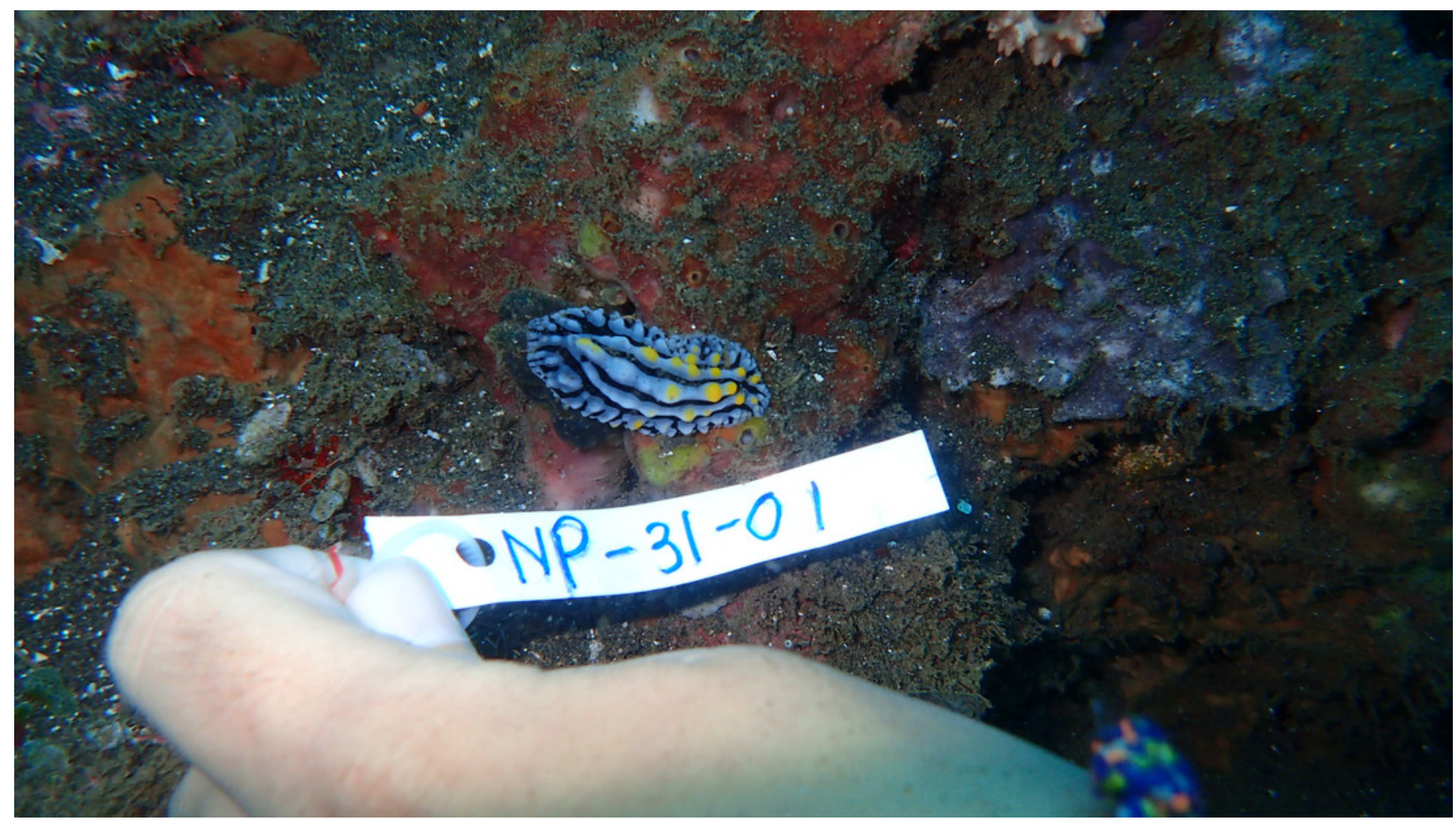




\section{Figure 2}

Underwater photographs of the nudibranch; (B) Phyllidia coelestis from Karimunjawa, Jepara Indonesia.

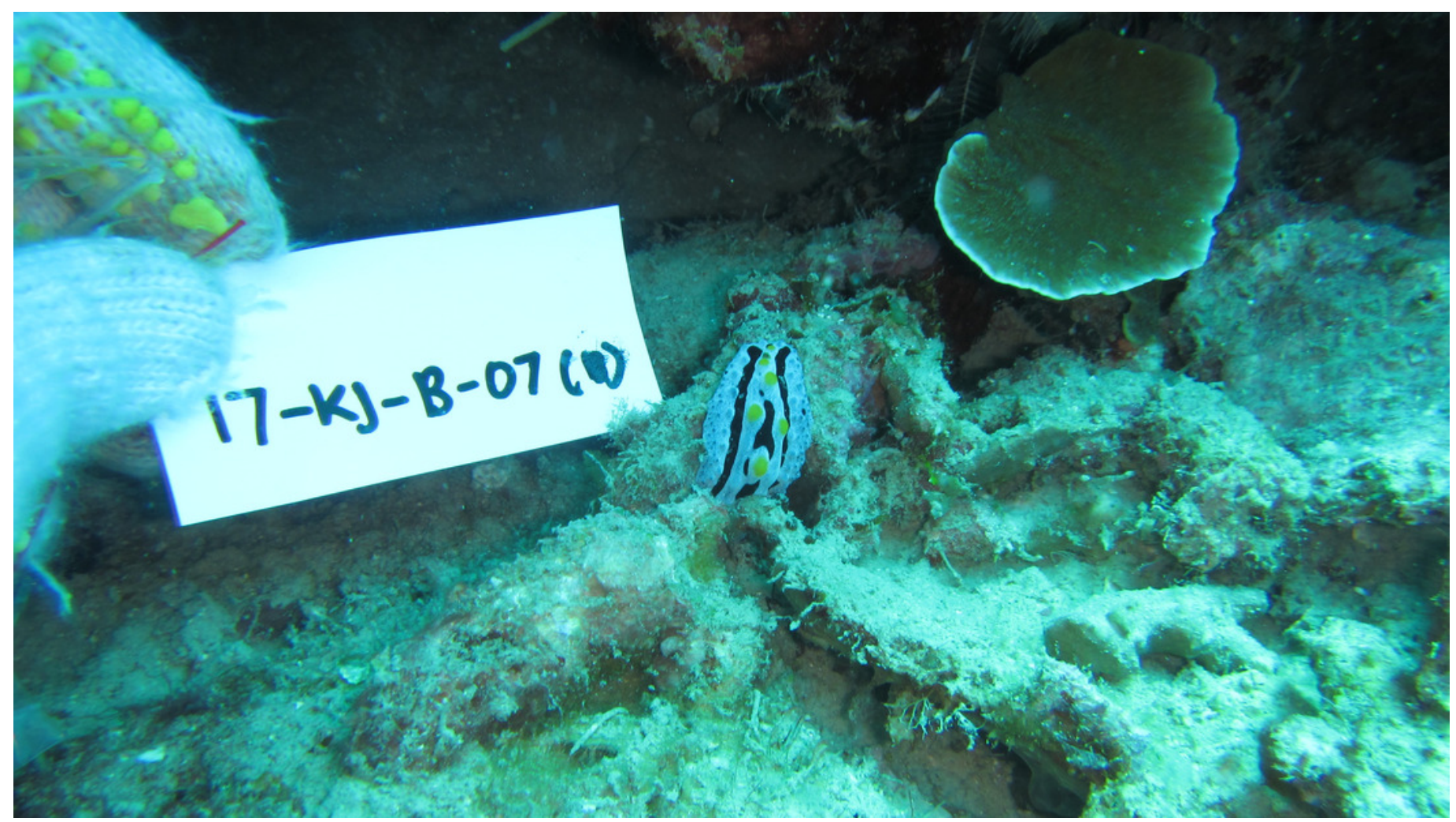


Figure 3 (on next page)

Isolation of bacteria symbiont from the surface $(A)$; viscera 


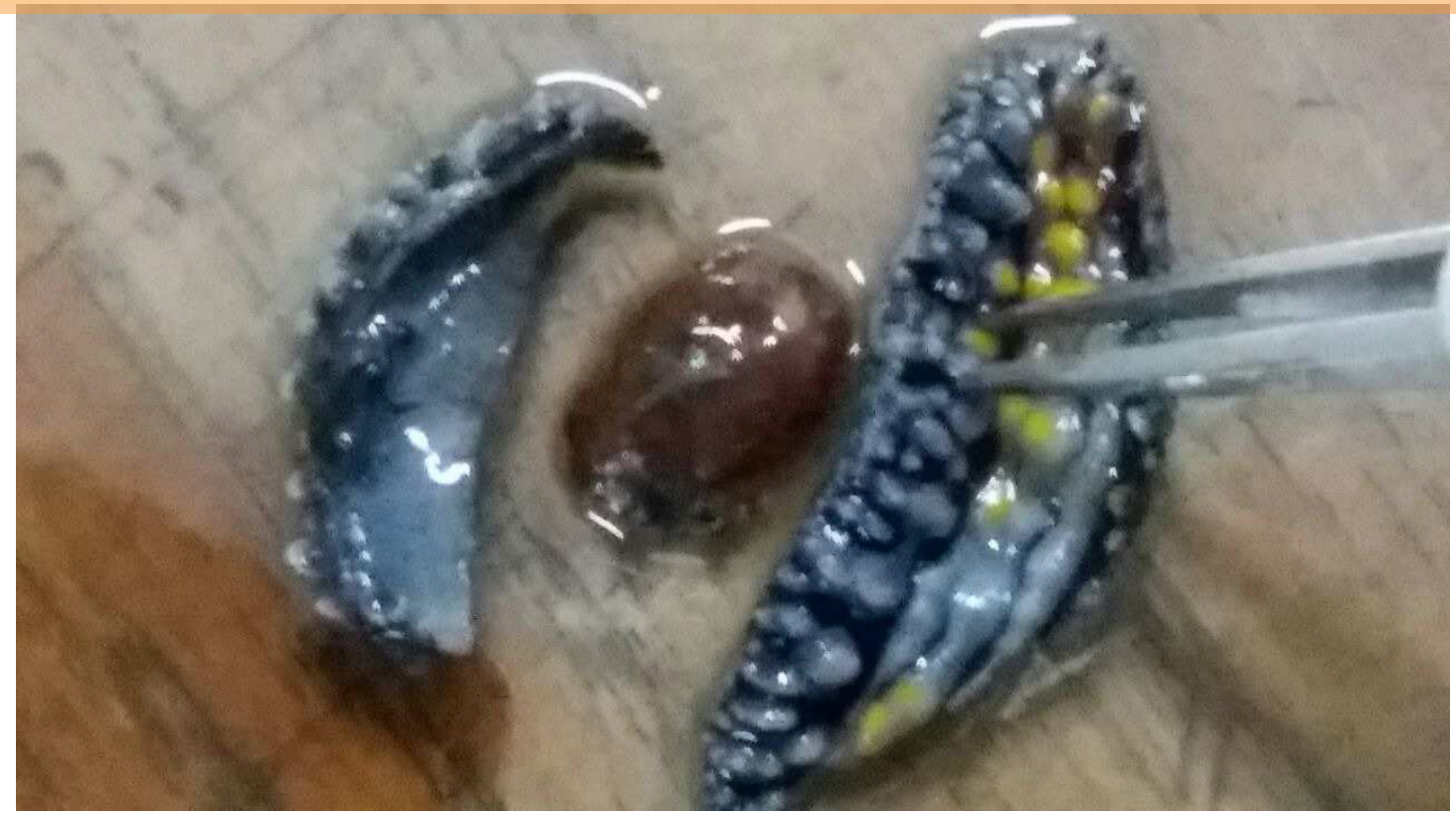


Figure 4 (on next page)

Isolation of bacteria symbiont from the surface (B) of Phyllidia varicosa; flowchart of isolation of symbiont bacteria. 


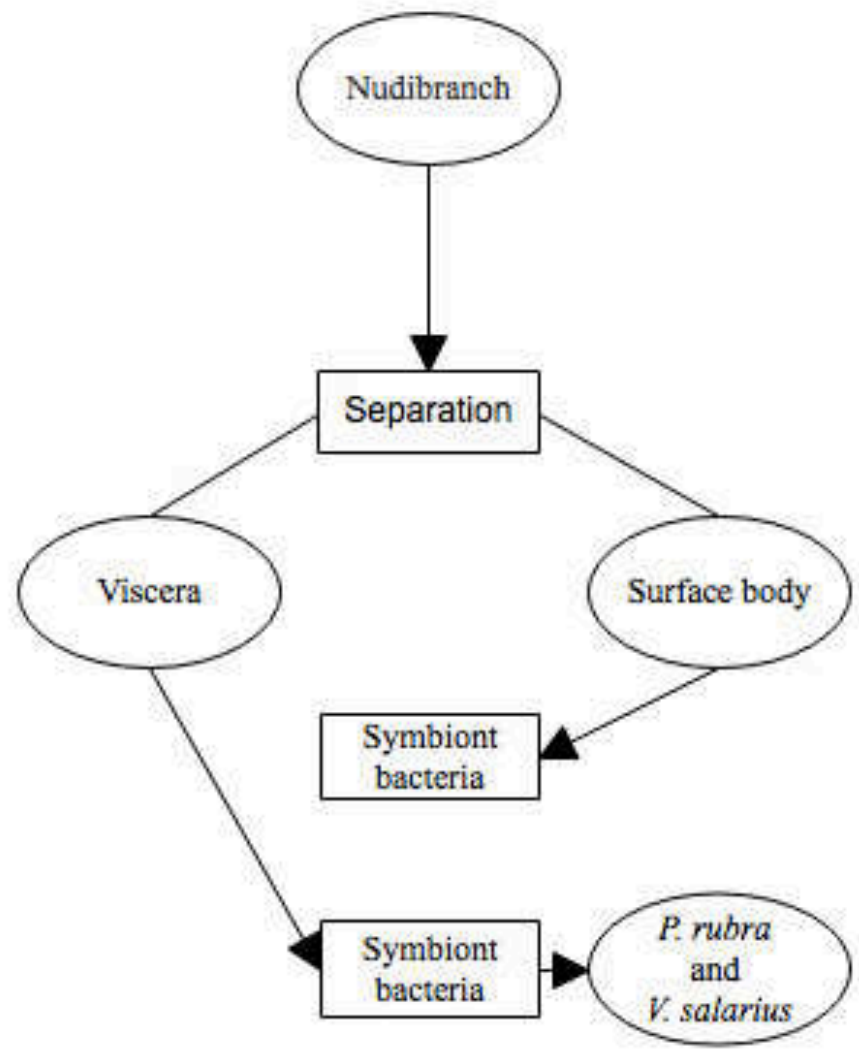




\section{Figure 5}

Active isolate symbiotic bacteria of nudibranchs against MRSA; (A) NP31-01 symbiotic Phyllidia varicosa.

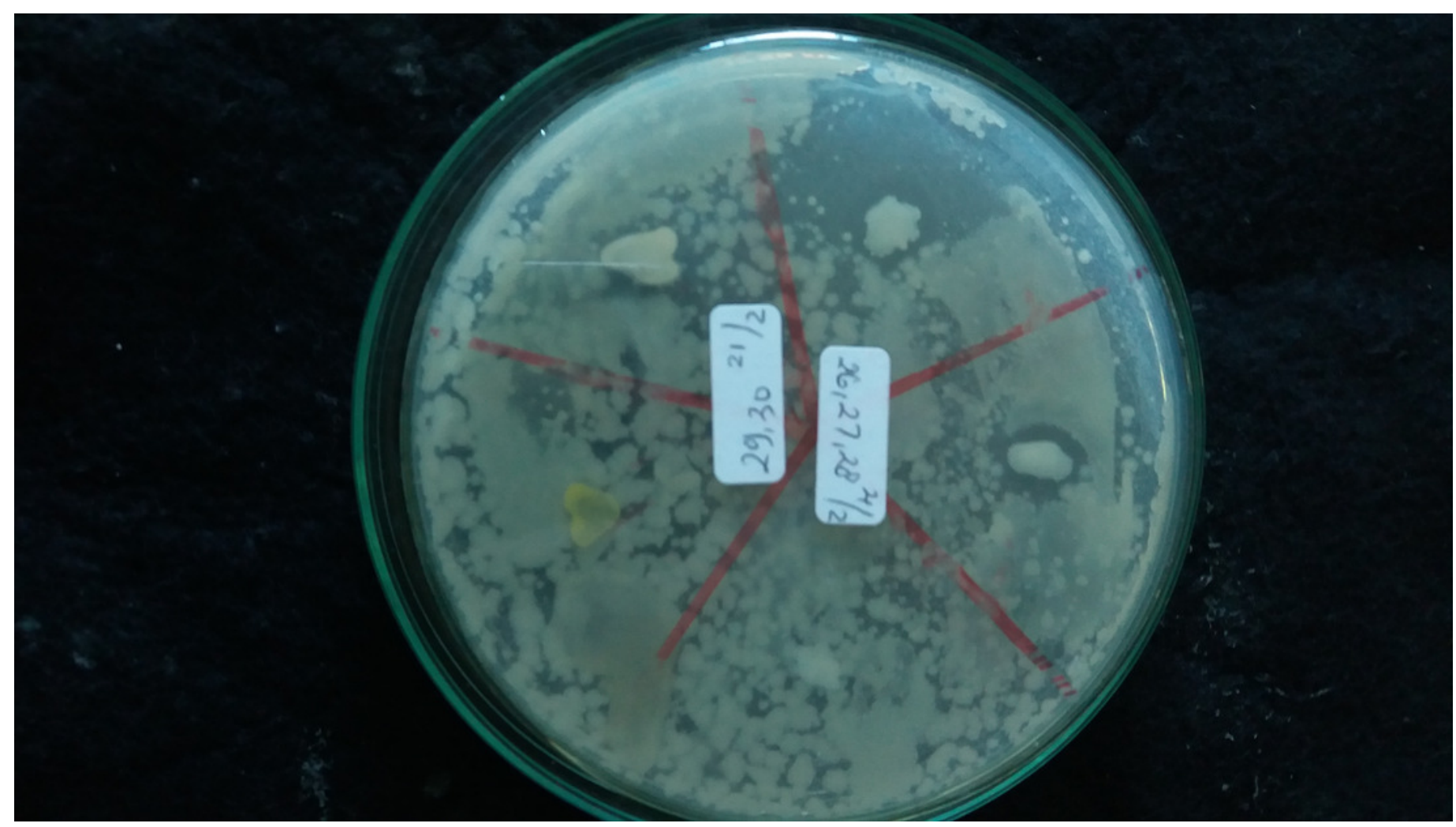




\section{Figure 6}

Active isolate symbiotic bacteria of nudibranchs against MRSA; (B) KJB-07symbiotic Phyllidia coelestis.

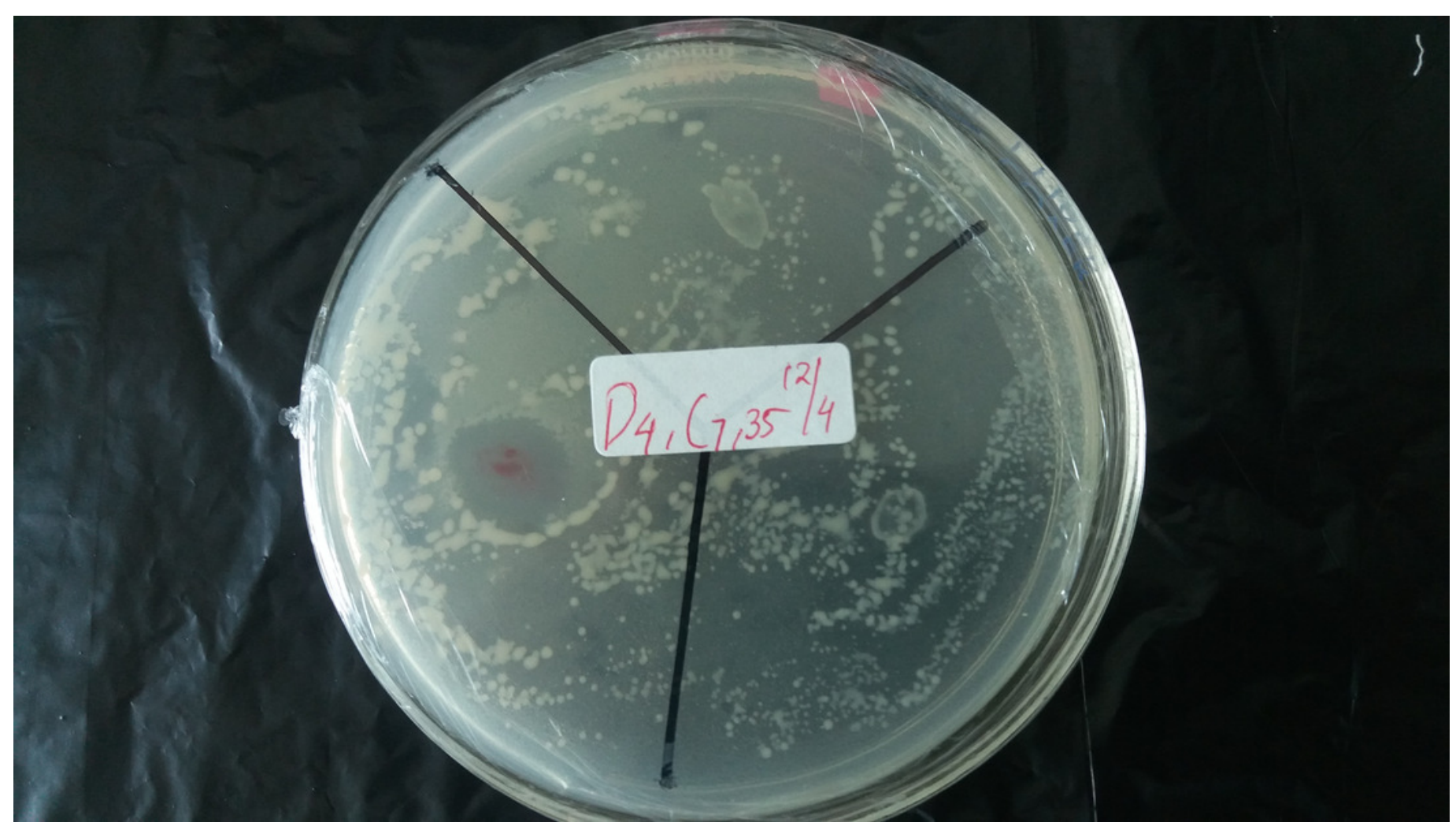


Figure 7 (on next page)

Phylogenetic tree of bacteria associated with nudibranch isolated from Karimunjawa National Park and Bali, Indonesia. Thermus kawarayensis KW11 was used as the outgroup. 


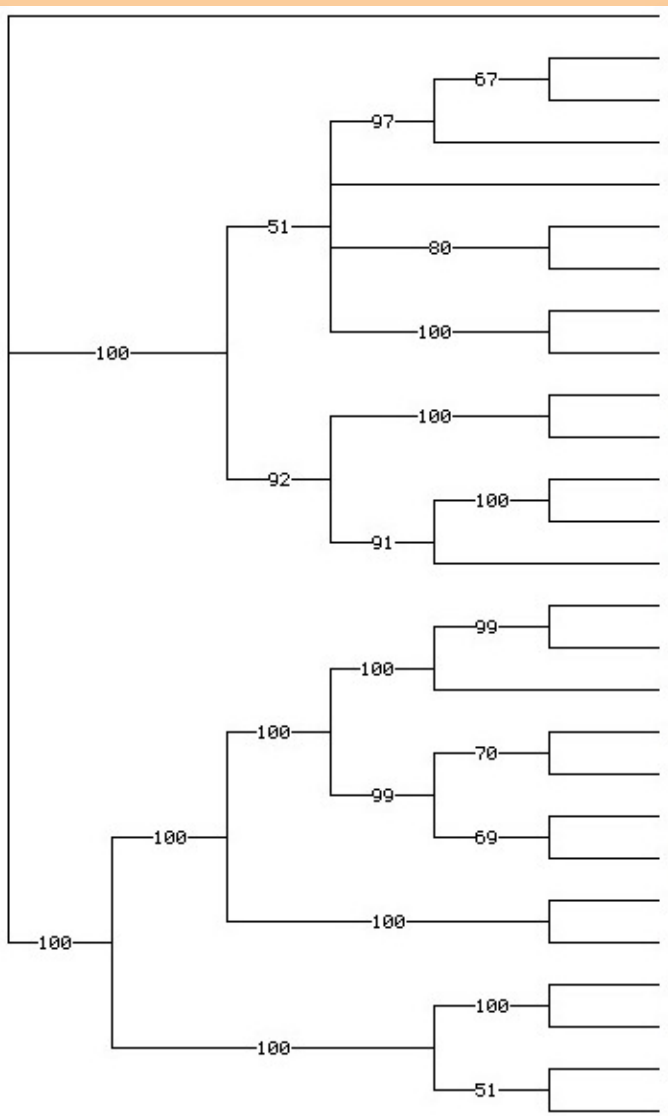

Thermus kawarayensis strain KW11 (NR_112160)

Virgibacillus marismortui strain SB-16 (MF_321845)

Virgibacillus salarius strain SB-11 (MF_321849)

Virgibacillus olivae strain R530 (HM_179193)

NP31-01 isolate

Virgibacillus chiguensis strain Halo30-9 (EF_101168)

Virgibacillus proomii strain EH10 (GU_339240)

Virgibacillus carmonensis strain LMG 20964 (NR_025481)

Virgibacillus necropolis strain LMG 19488T (AJ_315056)

Bacillus pichinotyi strain YAM2 (JX_203257)

Bacillus depressus strain LNHL5 (MG_008670)

Bacillus subterraneus strain COOBB (NR_104749)

Bacillus boroniphilus strain CM25 (EU_660347)

Bacillus foraminis strain XJSL3-9 (GQ_903408)

KJB-07 isolate

Pseudoalteromonas rubra strain ATCC 29570 (NR_026223)

Pseudoalteromonas viridis strain P1 (EU_240534)

Pseudoalteromonas piscicida strain P1-14-1a (KY_382776)

Pseudoalteromonas flavipulchra NCIMB 2033 (NR_025126

Pseudoalteromonas citrea strain BF21e (HQ_439546)

Pseudoalteromonas peptidolytica strain OS-3M-3 (KY366348)

Pseudoalteromonas marina strain D5053 (F_161291)

Pseudoalteromonas porphyrae strain BM2 (FJ_205739)

Halomonas salina strain $2 \mathrm{YNB} 1$ (EF_517963)

Halomonas koreensis strain SS20 (NR_025773)

Halomonas organivorans strain G-16.1 (NR_029029)

Halomonas halophila strain CCM 3662 (NR_042697) 


\section{Figure 8}

Typical TLC photography of ethyl acetate extract of P.rubra; (A) stearidonic acid, (B)

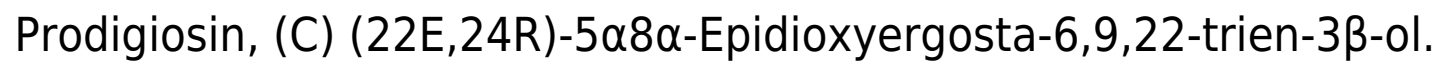

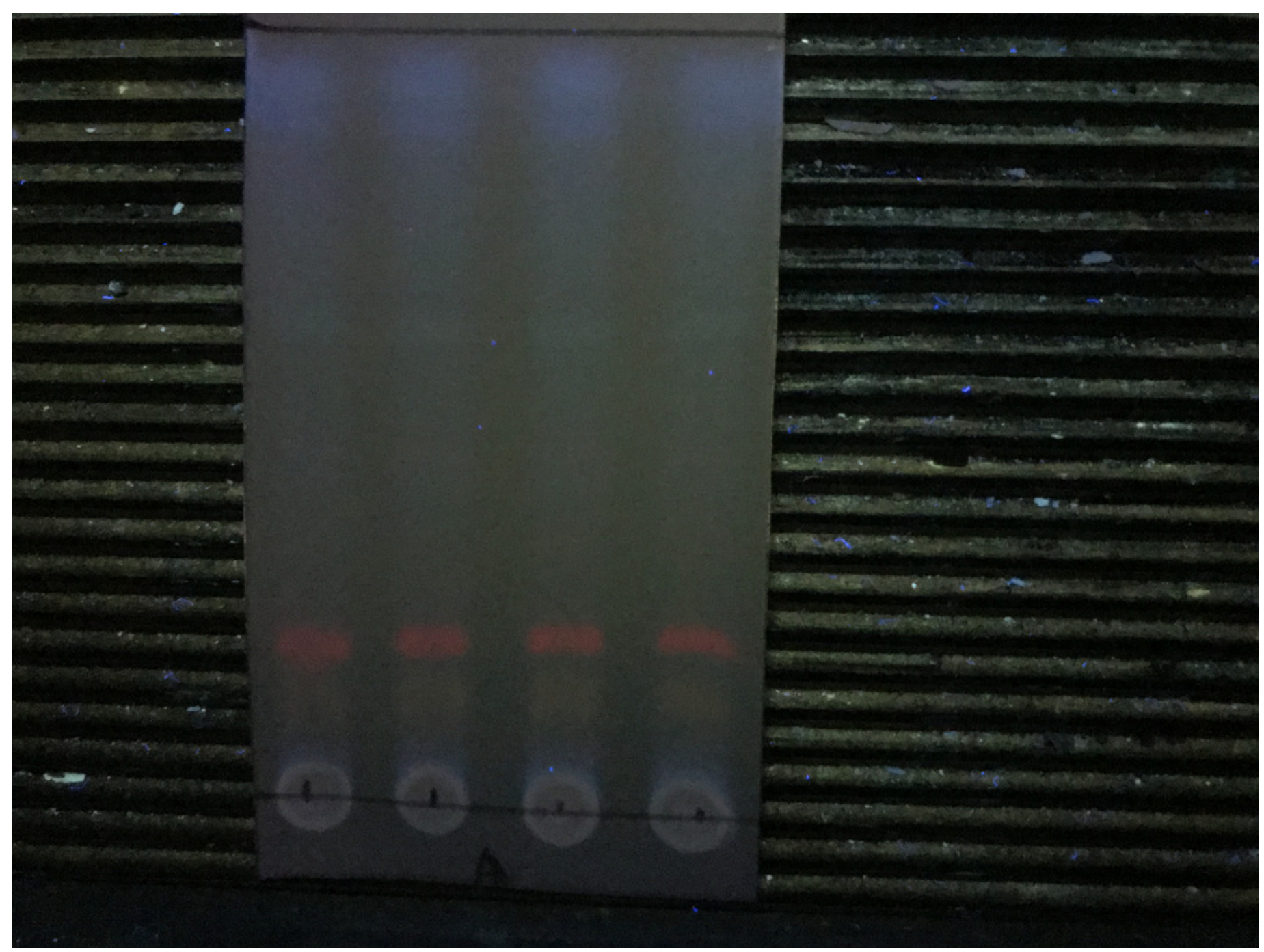


Figure 9 (on next page)

LSMS/MS Chromatogram of three compounds (A) stearidonic acid, (B) Prodigiosin, (C) (22E,24R)-5 $\alpha 8 \alpha$-Epidioxyergosta-6,9,22-trien-3 $\beta$-ol. 


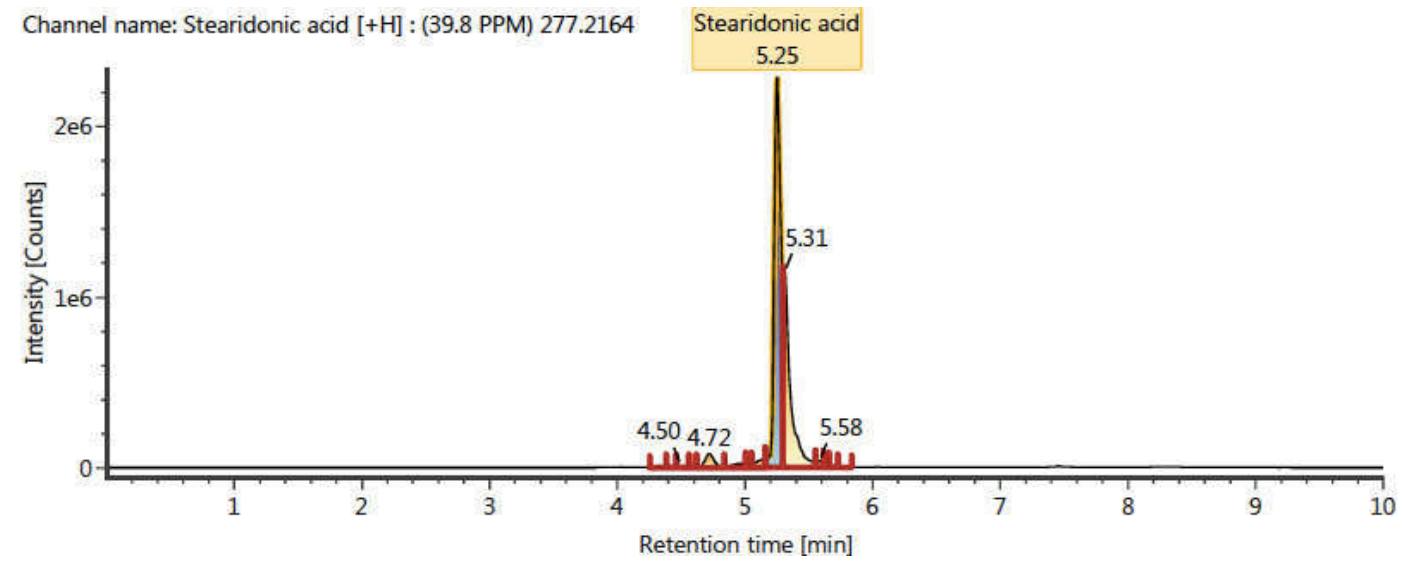

A

Channel name: 1: +324.2901 (39.8 PPM) +325.2933 (39.8 PPM) +326.2962 (39.8 PPM) : TOF MSE (100-1200) 6eV ESI+ - Low CE : Integrated: Smoothed

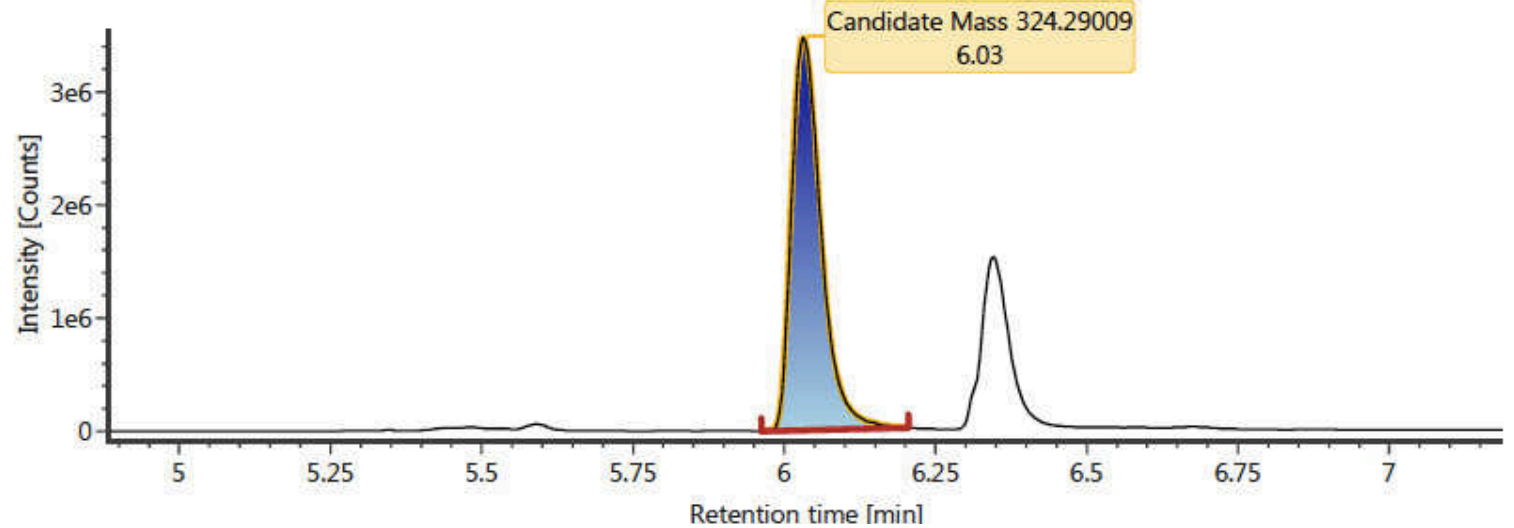

B

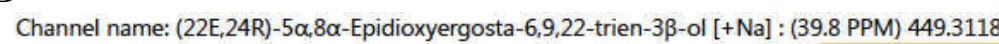

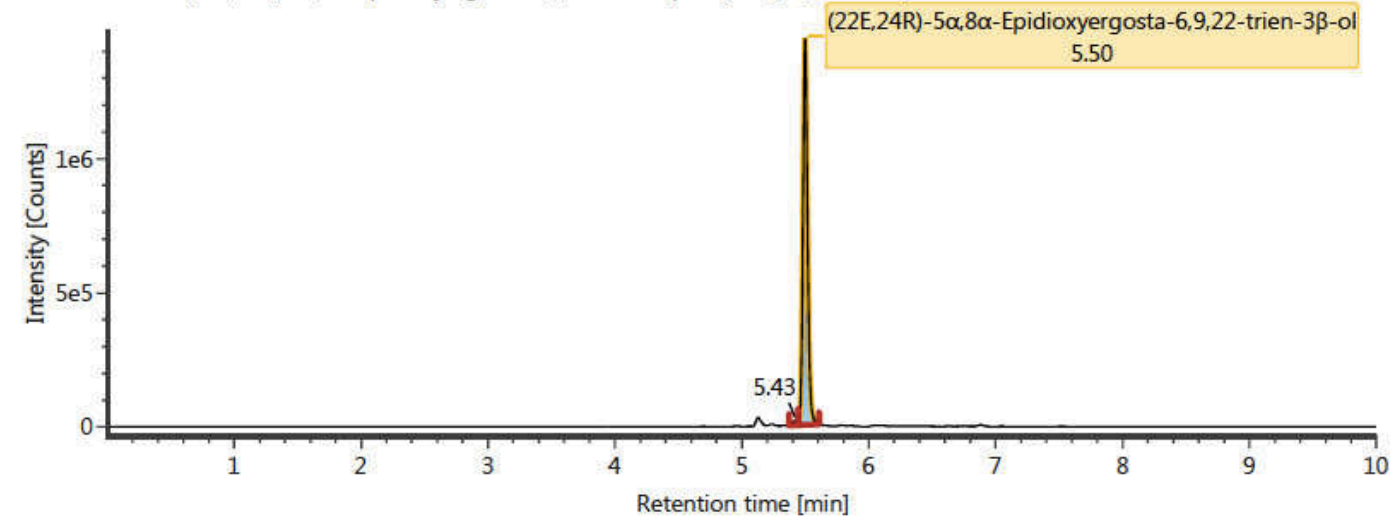

C 